\title{
Typology of Sounding Curves and Lithological 1D Models of Mineral Prospecting and Groundwater Survey within Crystalline Basement Rocks in the East of Cameroon (Central Africa) Using Electrical Resistivity Method and Koefoed Computation Method
}

\author{
Daniel Hervé Gouet $\mathbb{D},{ }^{1}$ Arsène Meying $\mathbb{D}^{2},{ }^{2}$ Harlin Leonid Ekoro Nkoungou, ${ }^{3}$ \\ Stephane Patrick Assembe, ${ }^{4}$ Philippe Njandjock Nouck, ${ }^{3}$ and Théophile Ndougsa Mbarga $\mathbb{D D}^{5}$ \\ ${ }^{1}$ Department of Mines, Oil, Gas and Water Resources Exploration, Faculty of Mines and Petroleum Industries, University of Maroua, \\ P.O. Box 08 Kaélé, Far North, Cameroon \\ ${ }^{2}$ Department of Applied Geophysics, School of Geology and Mining Engineering, University of Ngaoundere, \\ P.O. Box 115 Meiganga, Cameroon \\ ${ }^{3}$ Department of Physics, Faculty of Science, University of Yaounde I, P.O. Box 812 Yaounde, Cameroon \\ ${ }^{4}$ Postgraduate School of Science, Technology and Geosciences, University of Yaounde I, P.O. Box 812 Yaounde, Cameroon \\ ${ }^{5}$ Department of Physics, Advanced Teacher's Training College, University of Yaounde I, P.O. Box 47 Yaoundé, Cameroon
}

Correspondence should be addressed to Daniel Hervé Gouet; gouetdanyl@yahoo.fr

Received 7 April 2019; Revised 28 September 2019; Accepted 16 October 2019; Published 28 February 2020

Academic Editor: Yun-tai Chen

Copyright (c) 2020 Daniel Hervé Gouet et al. This is an open access article distributed under the Creative Commons Attribution License, which permits unrestricted use, distribution, and reproduction in any medium, provided the original work is properly cited.

\begin{abstract}
Resistivity method using seventy-sixth (976) Schlumberger vertical electrical soundings along forty-one (41) profiles are conducted in the Batouri and Ngoura subdivisions, East region of Cameroon, to investigate the subsurface layering, mineral potential, and groundwater resource characteristics. Results of quantitative and qualitative interpretation of data using Koefoed computation method reveal two to five layers having geometrical and electrical characteristics of geological layer models: topsoil $\left(0.5 \mathrm{~m}<e_{p}<3 \mathrm{~m} ; 600<\rho<3000 \Omega\right.$.m), lateritic soils $\left(3<e_{p}<20 \mathrm{~m} ; 1000<\rho<4000 \Omega\right.$.m); conductive layer $\left(5<e_{p}<110 \mathrm{~m} ; 100<\rho<1000 \Omega . \mathrm{m}\right) ;$ fractured/weathered granite $\left(20<e_{p}<60 \mathrm{~m} ; 1000 / 5000<\rho<3000 / 9000 \Omega\right.$.m); clayey layer $\left(5<e_{p}<20 \mathrm{~m} ; 600 / 1500<\rho<2000 / 3500\right.$ (dry) $\left.\Omega . \mathrm{m}\right)$; and fresh granites $(\rho>4000 \Omega . \mathrm{m})$. From the qualitative interpretation of VES curves, the subsurface layering is depicted by nine (09) types of sounding curves $(\mathrm{G}, \mathrm{H}, \mathrm{A}, \mathrm{QH}, \mathrm{KH}$, $\mathrm{HK}, \mathrm{HA}, \mathrm{HKH}$, and $\mathrm{KHK}$ ) characterizing the vertical changes and the typology of sounding curves in the East Cameroon crystalline basements. The lithology of the subsurface is dominated (more than $80 \%$ ) by geoelectrical and lithological $1 \mathrm{D}$ models derived by the $\mathrm{H}, \mathrm{QH}, \mathrm{KH}, \mathrm{HK}, \mathrm{HA}, \mathrm{HKH}$, and $\mathrm{KHK}$ curve types. These models are characterized by the presence of conductive layers and fractured/weathered granites derived from tectonic activities of the region. Also, the resistivity method (VES) applied in this study bring information about variation of the resistivity with depth, geological structures, fractures, and rupture zones in the underground until $120 \mathrm{~m}$ depth. These abovementioned information reveal proper hydrogeological and mining conditions for an efficient evaluation of the mineral potential and groundwater resources.
\end{abstract}

\section{Introduction}

Groundwater and mineral resources are very important for a sustainable development of a locality. Groundwater is the only source of water in many areas where development of surface water is not economically viable. Its accumulation in alluviums and immature sedimentary rocks is in pore spaces, whereas in compact sedimentary, igneous, and metamorphic rocks, it is largely due to secondary porosity and permeability resulted from weathering, fracturing, jointing, 
and faulting activities [1]. Mineral deposits are the attractive sources of capital investments from foreign countries, and the discovery of minable substances can therefore create employment in a local and regional scale. Deposited grains are mainly scattered within alluvial, eluvial, and colluvial materials and lithified clasts [2-6], whereas ore bodies in igneous and metamorphic terrains are generally found in specific structures such as lineations, veins, veinlets, faults, and folds $[7,8]$. Thus, prospecting for groundwater resources and minable substances, although of interest, is complicated.

Small-scale gold mining activities are common and currently going on in Batouri and Ngoura subdivisions in the East Region of Cameroon. Miners mainly extract gold from superficial materials. Consumed surface water in these localities is not of quality. With the aim to discover viable groundwater source and primary gold occurrence "deposits" in those localities, geophysical survey was carried out in seven villages (Bougmama, Wallo, Mama I, Mama II and Garoua Sambe in Batouri subdivision; Tassongo and Colomine in Ngoura subdivision). This survey carried out within crystalline basement formations was done with the geoelectrical method. The electrical nature of $1 \mathrm{D}$ model layers helps to have an idea for the groundwater and economic mineral potential within the surveyed crystalline basement formations.

\section{Geographic and Geologic Setting}

The area of study (Figures 1(a) and 1(b)) is made up of two sites: site 1 and site 2 . Site 1 (Figure 1(a)) is located in the Ngoura subdivision in the heart of the Eastern region of Cameroon. Its boundaries stretches from $14.296^{\circ}$ to $14.472^{\circ}$ eastward and from $4.921^{\circ}$ to $5.054^{\circ}$ in the north direction (Figure 1(a)). Site 2 (Figure 1(b)) is located in the Batouri subdivision in the heart of the Eastern region of Cameroon. It stretches from $14.254^{\circ}$ to $14.396^{\circ}$ eastward and from $4.521^{\circ}$ to $4.732^{\circ}$ northward.

The surveyed localities are found in the transition zone between the Pan-African domain and the Congo Craton in the northern edge of the Cameroon faults' zone $[9,10]$. This transitional zone is essentially composed of partly outcropping Precambrian age metamorphic and magmatic basement rocks $[11,12]$. These are mainly granites and migmatites rejuvenated during the Pan-African orogeny $[10,12]$. Other rocks (Figure 2(a)) identified by Gazel and Giraudie [13], Regnoult [14] and Mvondo et al. [12] are as follows:

(i) Biotite and muscovite quartzites, sericitic muscovite and conglomeratic quartzites, chloritic and sericitic schists, paraamphibolites, orthogneisses, biotite gneisses, pegmatites, and quartz veins (Figure 2(b)) all of the Precambrian basal complex (ages from 2.5 and 1.8 billion years)

(ii) Calcoalkaline granites (with porphyritic and alkali facies), granodiorites and syenites (containing heterogeneous and undifferentiated biotite facies), quartz-diorites, mica-schists, migmatites, and embrechite gneisses (iii) The main sedimentary rocks encountered are sandstones, sand, marl, limestones, and Paleozoic and Mesozoic conglomerates $[13,14]$.

(iv) Soils are red ferrallitic or lateritic on the hills and plateaus and the geological cover of the study area can be seen in artisanal mining pits [15].

The tectonic of the area is characterized by four deformations phases (D1, D2, D3, and D4: [11, 16]).

The tectonic setting of the areas similar to that of the Central Africa Pan-African chain [17] is characterized by four ductile and/or brittle-ductile deformation phases (D1, D2, D3, and D4: [11, 16]), buried faults, and nappe features [18-20]. For Olinga et al. [16], the Pan-African deformation which affected the study localities was controlled by tectonic thrusts and late strike-slip shear zones. The thrusting of the Pan-African Nappe over the Congo Craton (D2 deformation phase) is followed by a strikeslip shearing trending ENE-WSW (D3 deformation phase). During these two stages, deforming conditions were ductile to brittle-ductile. The dominant structural features for the D3 phase are penetrative foliation (steeply dipping $\mathrm{N}$ or S), an association ENE-WSW stretching lineations, and a N-S to NE-SW fold [11, 16]. A dextral transpressional model was assumed to explain the observed thrust and shear movements [16].

Plans of movement of northern flake lean toward the south and the meridional flake toward the north was due to compressive tectonics [17]. For Njonfang et al. [17], the region was compressed in the N-S direction between two blocks and it resulted in shear movements which pushed the region outside the central part. During this process, channels, faults, fractures, and shear zones were created (Wippern and Seyferle, 1966; [17]). Magmatic activities are materialized by the infilling of fractures, faults, and shear zones by pegmatite and quartz-rich veins (Figure 2(b)).

Groundwater is the water filling the pore spaces in rocks. Sedimentary materials and fractured crystalline rocks commonly form aquifers or reservoirs. Clays, shales, intrusive igneous bodies, and metamorphic rocks are common aquitards and are typically characterized by insignificant interconnected pore spaces. The nature and distribution of aquifers and aquitards are controlled by geological and geomorphological factors (Palacky et al., 1981; [21]). Typical geological environments for groundwater occurrence include alluvial fill and gravel beds overlying crystalline bedrock or other impervious material, sand and gravel, and fault and fracture zones in crystalline basement rocks (Palacky et al., 1981; [21]).

\section{Electrical Resistivity Method}

3.1. Principle. Electrical resistivity method consists of injecting an electrical current in the ground between two electrodes $\mathrm{A}$ and $\mathrm{B}$, and then measuring the induced potential drop between two other electrodes $\mathrm{M}$ and $\mathrm{N}$ called potential electrodes (Figure 3). 


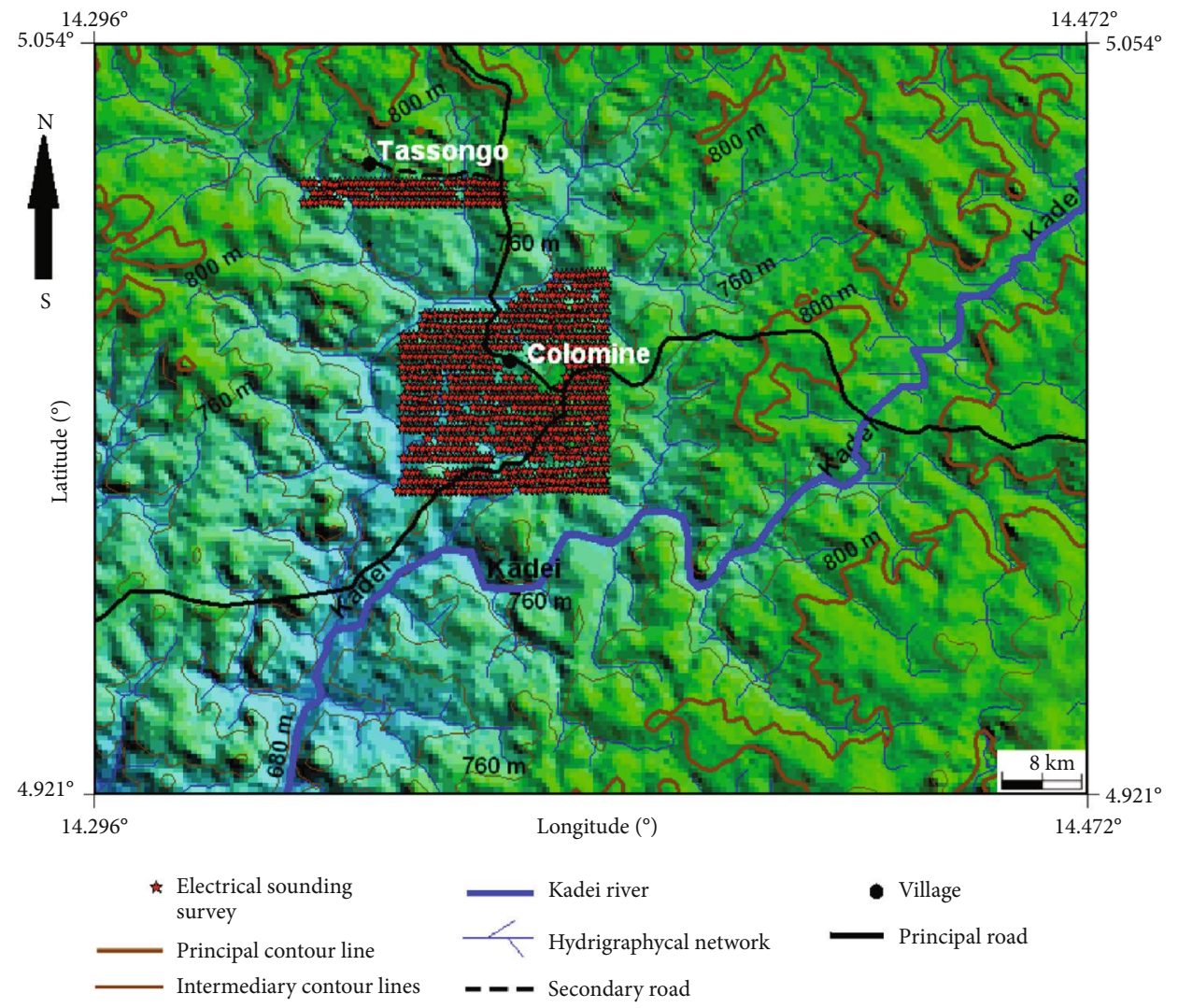

(a)

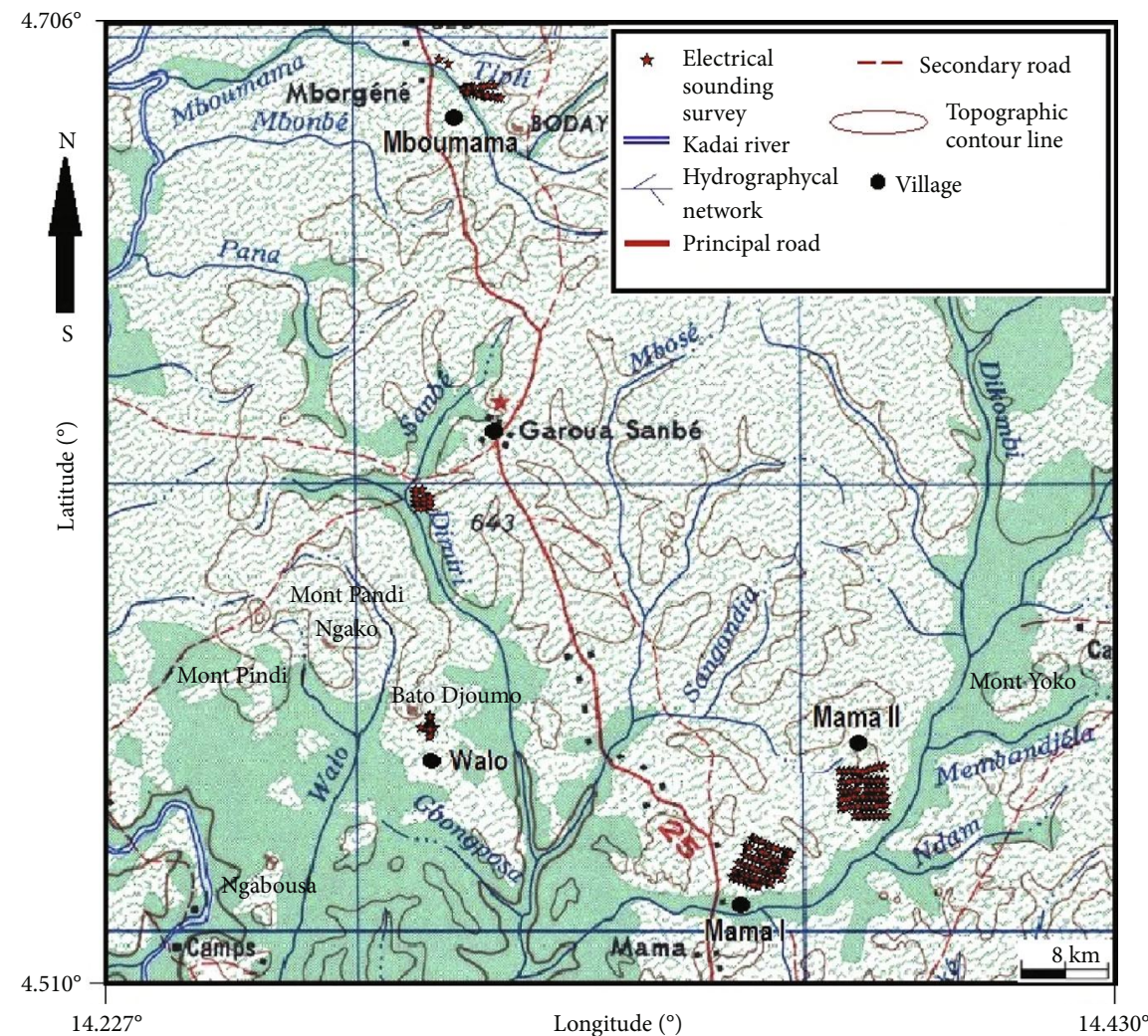

(b)

Figure 1: (a) Localization map of electrical soundings and study area (area 1). (b) Localization maps of electrical soundings and study area (area 2). 


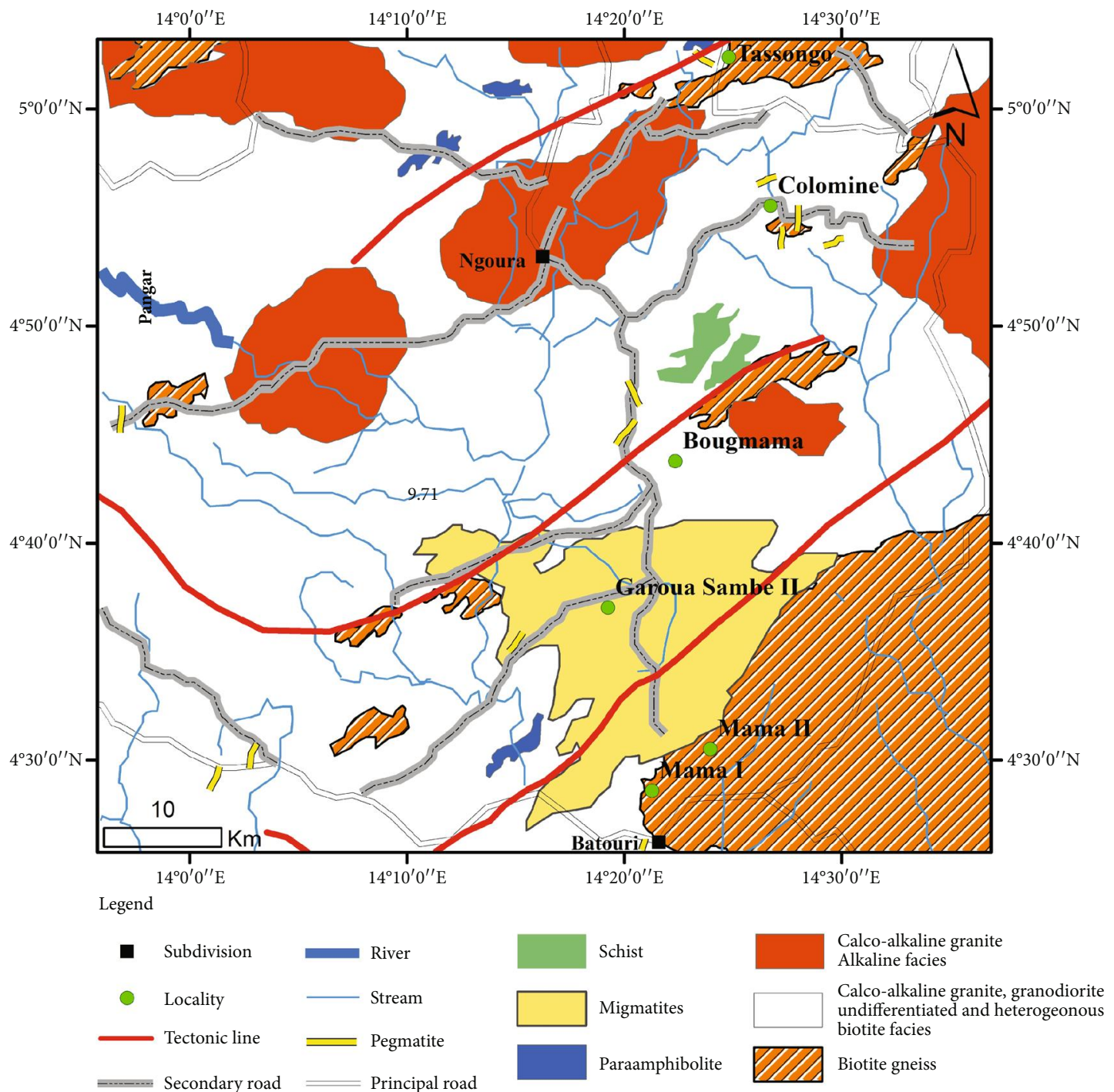

(a)

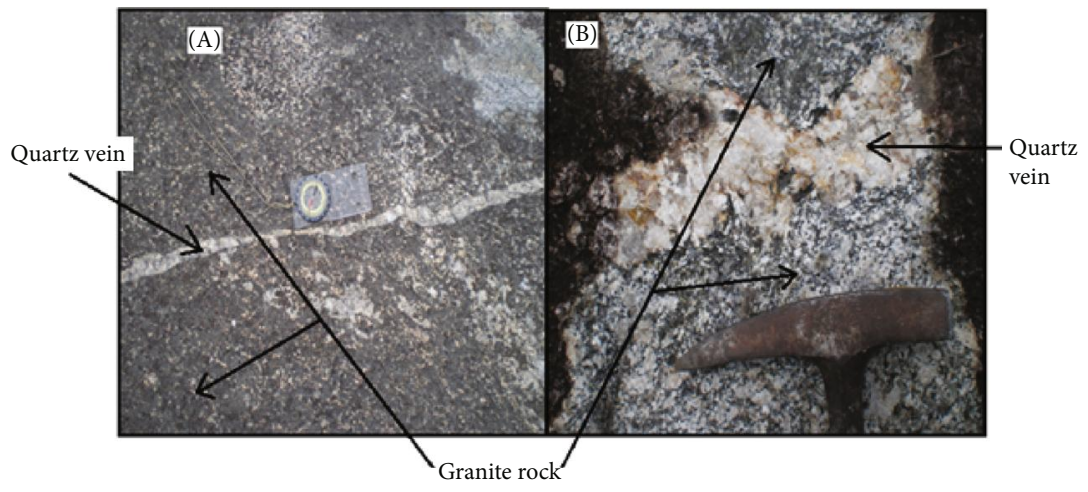

(b)

FIgURe 2: (a) Geological map of the study area [13]. (b) Outcrops of quartz vein (A) and granite rock (B) observed in the study area. 


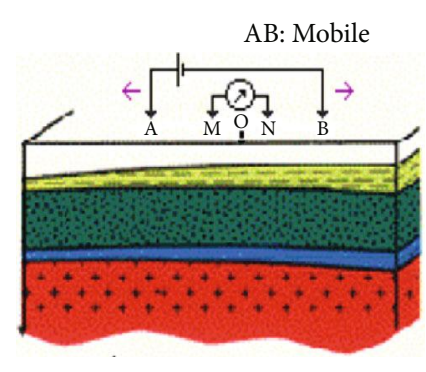

(a)

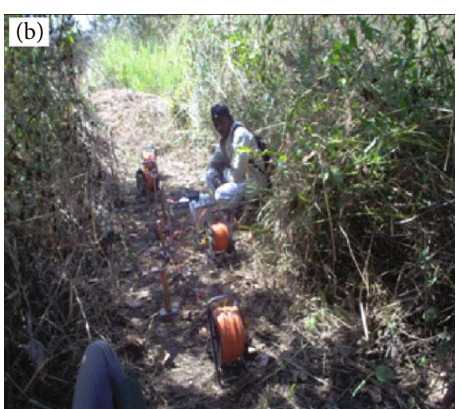

(b)

Figure 3: (a, b) Schlumberger electrical sounding method.

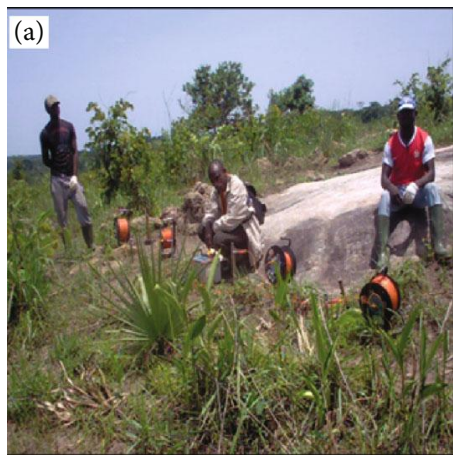

(a)

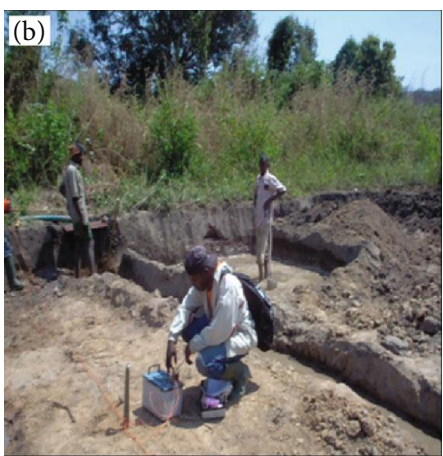

(b)

FIgURE 4: Electrical sounding test near the granite outcrop (a) and the mining site (b).

If the injected current intensity is known and the potential drop measured, it is therefore possible to determine the apparent resistivity $\rho_{\mathrm{a}}$ (Rho) of the ground following formulae below [22-24]:

$$
\rho_{\mathrm{a}}=2 \pi\left(\mathrm{AM}^{-1}-\mathrm{AN}^{-1}-\mathrm{BM}^{-1}+\mathrm{BN}^{-1}\right)\left(\frac{V_{\mathrm{MN}}}{I_{\mathrm{AB}}}\right)
$$

where $\rho_{\mathrm{a}}$ is the apparent resistivity in Ohm.m; AM and AN are the distance between current electrode $\mathrm{A}$ and potential electrodes $\mathrm{M}$ and $\mathrm{N}$, respectively, in meter (m); BM and $\mathrm{BN}$ are distance between current electrode $\mathrm{B}$ and potential electrodes $\mathrm{M}$ and $\mathrm{N}$, respectively, in meter $(\mathrm{m}) ; V_{\mathrm{MN}}$ is the potential drop between potential electrodes $\mathrm{M}$ and $\mathrm{N}$, in $\mathrm{mV} ; I_{\mathrm{AB}}$ is the electric current injected between current electrodes $A$ and $\mathrm{B}$, in $\mathrm{mA}$.

For the Schlumberger symmetrical configuration (Figure 3), the apparent resistivity $\rho_{\mathrm{a}}$ is given by Equation (2) as follows [22-24]:

$$
\rho_{\mathrm{a}}=\pi / 4\left(\frac{\mathrm{AB}^{2} V_{\mathrm{MN}}}{\mathrm{MN} I_{\mathrm{AB}}}\right) .
$$

This resistivity value enables to characterize a formation at the point $(\mathrm{O})$ or station (Figure 3 ). The resistivity of an earth's material depends essentially on the humidity and the clay proportion in a given volume of that material $[22,23,25,26]$. While clay and water fill in any vacuum in a rock, one can assume that the resistivity is a function of parameters such as fracturing, fractures and fissures clayey filling, porosity, and the clayey clogging of alluvium $[22,23,25,26]$. Thus, the resistivity of fractured granites and clayey clogging of alluvium are lower than fresh granite (basement) and the barren stratum in the study area.

3.2. Vertical Electrical Sounding Theory. The vertical electrical sounding (VES) theory is an investigation technique which enables the downward assessment of the successive layers by determining their apparent resistivity and thickness values [25, 27-29]. The value of the resistivity characterizes a lithology without providing information upon its water bearing or its mineralization [25, 27-29]. However, it aids in comparing two lithologies and locating them from one another. That is, for a given geological layer, water-bearing strata and sterile (dry) strata do not exhibit the same resistivity.

In geophysical investigation, two types of soundings are used during a campaign [25]:

(i) The parametric soundings: they are set at the beginning of the first phase of a geophysical survey or reconnaissance stage. Since the a priori distribution of the resistivity in a region is unknown, they are 
TABle 1: Example of the VES paper.

\begin{tabular}{|c|c|c|c|c|c|}
\hline \multicolumn{6}{|c|}{ Schlumberger vertical electrical sounding } \\
\hline \multicolumn{2}{|c|}{ Sounding: BK1 } & Operator: Dr. Gouet & \multicolumn{2}{|c|}{ Locality: Colomine } & Date: $08 / 05 / 2013$ \\
\hline \multicolumn{2}{|c|}{ Region: East Cameroon } & \multicolumn{4}{|c|}{ Instrument: Syscal junior resistivimeter } \\
\hline \multicolumn{2}{|c|}{ Position: $X=250 \mathrm{~m}$} & \multicolumn{4}{|c|}{ Coordinate $(33 \mathrm{~N} ; 431752 \mathrm{mE} 550183 \mathrm{~m} \mathrm{~N}$; alt $=755 \mathrm{~m})$} \\
\hline $\mathrm{N}^{*}$ & $\mathrm{AB} / 2(\mathrm{~m})$ & $\mathrm{MN} / 2(\mathrm{~m})$ & $I(\mathrm{~mA})$ & $V(\mathrm{mV})$ & $\rho(\Omega . \mathrm{m})$ \\
\hline 1 & 1.5 & 0.5 & 2.698 & 444.598 & 1035.41 \\
\hline 2 & 2.5 & 0.5 & 2.8 & 159.842 & 1076.06 \\
\hline 3 & 5 & 0.5 & 2.736 & 27.685 & 786.76 \\
\hline 4 & 7.5 & 1.5 & 2.501 & 25.091 & 567.21 \\
\hline 5 & 10 & 1.5 & 5.058 & 23.027 & 466 \\
\hline 6 & 15 & 1.5 & 11.365 & 20.948 & 429.96 \\
\hline 7 & 20 & 2.5 & 13.145 & 22.249 & 418.77 \\
\hline 8 & 25 & 2.5 & 19.721 & 21.208 & 418.08 \\
\hline 9 & 35 & 5 & 17.271 & 20.237 & 441.73 \\
\hline 10 & 50 & 5 & 27.794 & 20.132 & 563.2 \\
\hline 11 & 75 & 7.5 & 37.339 & 21.017 & 656.48 \\
\hline 12 & 100 & 10 & 42.111 & 20.037 & 739.91 \\
\hline 13 & 150 & 15 & 47.594 & 20.172 & 988.66 \\
\hline 14 & 200 & 20 & 49.591 & 19.962 & 1251.97 \\
\hline 15 & 250 & 25 & 50.234 & 19.951 & 1544.05 \\
\hline 16 & 300 & 30 & 50.399 & 20.527 & 1900.11 \\
\hline
\end{tabular}

set beside wells, drillings, or on outcrops (Figure 4). Therefore, they will help in assessing the resistivity framework of the area and in choosing the length of cables to be used for resistivity profiling

(ii) The interpretative soundings: they are set to confirm anomalies or discontinuities highlighted by past investigations. They also provide information on the vertical distribution of layers characterized by their true resistivities and thicknesses [25, 27-30]. They enable to plot cross-sections or geological section of the subsurface

In the framework of this study, soundings (parametric and interpretative) were realised using the Schlumberger array with $A B / 2$ varying from $1.5 \mathrm{~m}$ to $300 \mathrm{~m}$ and $\mathrm{MN} / 2$ from $0.5 \mathrm{~m}$ to $30 \mathrm{~m}$ (Table 1 ).

In the Schlumberger array, the distance between $\mathrm{A}$ and $\mathrm{B}$ varies as well as the distance between $\mathrm{M}$ and $\mathrm{N}$ (Figure 3 ). The obtained resistivity values correspond to the measured apparent resistivity values following Equation (3), at the centre $\mathrm{O}$ of the ABMN quadrupole (Figure 3).

The interpretation of data from interpretative sounding will enable to determine the thickness of the weathered zone, then that of the fractured zone or the discontinuity in the basement. It represents results of $1 \mathrm{D}$ inversion of the apparent resistivity as a function of electrode spacing (half current distance) $[25,27-31]$. The $1 \mathrm{D}$ inversion enables to deduce the true resistivity of the ground and from the resistivity, the composition of the different layers. It requires a $\log / \log$ diagram where half distance $\mathrm{AB}$ is the abscissa and the apparent resistivity, in Ohm.meter is the ordinate.
The data is processed, modelled, and interpreted using 1D inversion software WinSev 6.4 from Geosoft [31]. With this software, using the equivalence and suppression principles, it shows that each interpretative sounding curve realised is not unique [25]. Thus, the parametrical soundings and field geological data help to constraint resistivity and thickness models for each interpretative sounding curve [25].

\section{Koefoed Computation Method}

The computation of the theoretical curve uses the method described by Koefoed [32]. It can run on the W-GeosoftWinsev program developed by Miguel Borreguero and Jacques Jenny [31].

4.1. Theoretical Principle of the Koefoed Method. The potential at a point due to a point source of current over a layered earth described by Das and Verma [33] is given by

$$
U(s)=\frac{I}{2 \pi} \int_{0}^{\infty} T(\lambda) J_{0} \lambda s d \lambda,
$$

where $J_{0}(\lambda s)$ is the zeroeth-order Bessel function of the first kind, $T(\lambda)$ is the electrical impedance at the surface, defined by Koefoed [34] as the resistivity transform function of layer resistivities and thicknesses, and $\lambda$ is the integration variable.

Koefoed [32] also disassociated the resistivity transform function to extract the resistivity kernel function $K_{1}(\lambda)$ representing the deviation in response to the layered earth 
from that of a homogeneous half-space. Accordingly, at the air-earth interface,

$$
T_{1}(\lambda)=\rho_{1}\left[1+2 K_{1}(\lambda)\right]
$$

while at the top of the ith layer,

$$
T_{i}(\lambda)=\rho_{i}\left[1+2 K_{i}(\lambda)\right]
$$

From these basic expressions, Das and Verma [33] obtained the following simple expression for the apparent resistivity $\rho_{\mathrm{a}}(\mathrm{s})$ due to a two-electrode system and given by

$$
\rho_{\mathrm{a}}(s)=2 \pi s \frac{U(s)}{I}
$$

where $s=\mathrm{AM}$ is the separation between the two active electrodes.

From Equations (4) and (7), we have

$$
\rho_{\mathrm{a}}(s)=s \int_{0}^{\infty} T(\lambda) J_{0}(\lambda s) d \lambda
$$

The action of a linear filter can be defined by a convolution integral of the type (Das and Verma, 180):

$$
F=\int_{0}^{\infty} G(\lambda) H(x-y) d y
$$

where $F$ is the output function, $G$ is the input function, and $H$ is the filter function.

Equation (7) giving the apparent resistivity for the twoelectrode array can be expressed as a convolution integral by putting variables on a logarithmic scale as $x=\ln (s)$ and $y=\ln (/ / A)$. Thus, Equation (8) assumes the form [33]

$$
\rho_{\mathrm{a}}(x)=e^{x} \int_{-\infty}^{\infty} T(y) J_{0}\left(e^{x-y}\right)\left(-e^{-y}\right) d y
$$

or

$$
\rho_{\mathrm{a}}(x)=\int_{-\infty}^{\infty} T(y)\left[-J_{0}\left(e^{x-y}\right) \cdot e^{x-y}\right] d y .
$$

Comparing Equation (10) with Equation (8), we find that Equation (10) is a convolution integral, where $T(y)$ is the input function, $\rho_{\mathrm{a}}(x)$ is the output function, and $e^{x-y} J_{0} e^{x-y}$ is the filter function [33]. Thus, the convolution of the resistivity transform function with this filter yields the apparent resistivity values for the two-electrode system.

From the expression of the apparent resistivity $\rho_{\mathrm{a}}(s)$ for the two-electrode configuration, Das and Verma [33] obtained the following expression for the Schlumberger apparent resistivity $\rho_{\mathrm{aSch}}(s)$ :

$$
\rho_{\mathrm{aSchl}}(s)=\rho_{\mathrm{a}}(s)-s \frac{\partial \rho_{\mathrm{a}}(s)}{\partial s}
$$

4.2. Computation of Model Curves. To compute the twoelectrode apparent resistivity for a specific model, the resistivity transform $T_{1}$ for the model should be convolved with the filter set mentioned in the preceding section [33]. This function $T_{1}$ is computed for equal increments of $y=\ln l / \lambda$ from the following iterative expression valid for any number of layers [35]:

$$
T_{i-1}=\rho_{i-1} \frac{T_{i}+\rho_{i-1} \tanh \left(\lambda d_{i-1}\right)}{\rho_{i-1}+T_{i} \tanh \left(\lambda d_{i-1}\right)},
$$

where $T=T_{N}=\rho_{N}$ is the number of layers in the subsurface and $d_{i}$ is the thickness of the $i$ th layer. The above equation represents a stacking process of layers, beginning from the bottom, which finally yields $T_{1}$ at the surface. After computing the resistivity transform functions at equal intervals, they are convolved with the filter set (for horizontal coplanar loops, as already mentioned) to yield the apparent resistivity par $\rho_{\mathrm{a}}(x)$ for the two-electrode system as [33]:

$$
\rho_{\mathrm{a}}(\mathrm{s})=\sum_{k=0}^{n} C_{k} T\left(y_{k}\right) \rho_{\mathrm{a}}(x)=\sum_{k=0}^{n} C_{k} T\left(y_{k}\right),
$$

where $C_{k}$ are the filter coefficients, $y k=\ln (s)-n_{0}+k \ln$ $10 / 10, n_{0}$ is the abscissa of the first filter coefficient, and $n$ is the suffix of the last filter point used.

Using the above convolution expression, a theoretical two-electrode sounding curve was computed for a specific three-layer earth model; the result is very suitable [33]. We obtain also the similar result for a Wenner or Schumberger theoretical sounding curve [33]. Thus, Das and Verma [33] present a technique based on the concept of digital linear filtering to compute electrical sounding curves for electrode systems.

The computation of the theoretical curve uses the method described by Koefoed [32]. It can run on the WGeosoft-Winsev program developed by Miguel Borreguero and Jacques Jenny [31]. The program compute Schlumberger theoretical electrical sounding curves in the area study for earth models to three and five layers following the field apparent resistivity data. This computation permits to have thicknesses $\left(e_{P}\right)$ and true resistivity values $(\rho)$ of geological layers of the inversion of the apparent resistivity as a function of depth [33].

\section{Material and Data Acquisition}

For a suitable coverage of the study localities, data have been collected through nine hundred and seventy-six (976) electrical soundings along forty-one (41) profiles. The data acquisition is done following the vertical electrical sounding method using the Schlumberger array. The interstation spacing along profiles is 100 meters. The $\mathrm{AB}$ maximum length was held at $600 \mathrm{~m}$ to detect desired lithological formations at an approximate depth between 114 and 130 meters as proposed by Loke [36]. In the study area, the main directions of strains are N-S and ENE-WSW [16]; thus, profiles of sounding 


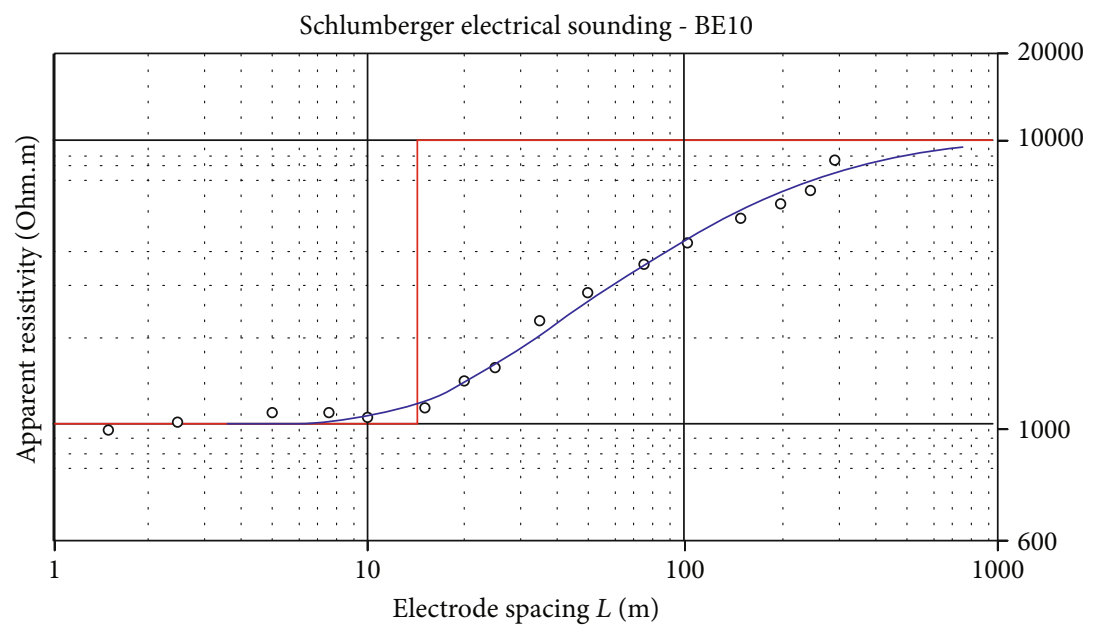

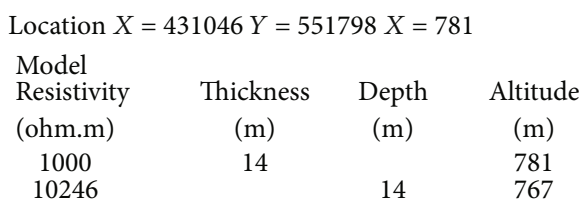

FIGURE 5: Sounding curve $\left(\mathrm{BE}_{10}\right)$ of type G.

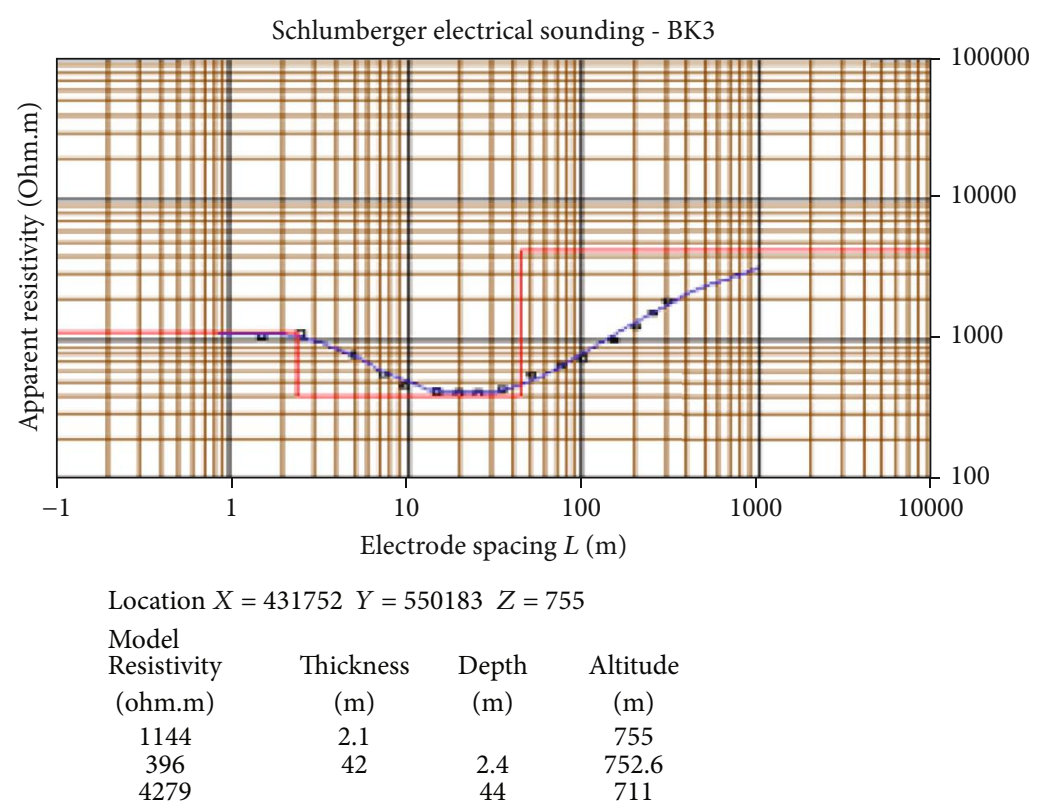

Figure 6: Sounding curve $\left(\mathrm{BK}_{3}\right)$ of type $\mathrm{H}$.

surveys were mainly oriented in the E-W and NNW-SSE directions (Figures 1(a) and 1(b)) in order to reduce the anisotropic effects by considering the $\mathrm{Su}$ and Yue [37] studies.

The direct current resistivity meter, Syscal Junior 48 (IRIS Instrument) system, was used. This unit runs under the Rho mode which enables one to measure the resistivity (Rho) of ground structures. Acquisition of electrical data were made using the Schlumberger electrical sounding method where the current was injected through A and B electrodes (Figure 3 ) and a potential was measured through receiving electrodes $\mathrm{M}$ and $\mathrm{N}$ [24].
The electrical soundings were interpreted by WinSev 6.4 software from Geosoft using the Borreguero and Jenny inversion program [31]. They allowed to obtain the ground distribution of layers at each station, hence, providing geoelectrical and geological 1D models of the study area.

\section{Results}

Results of the study were presented as typology of sounding curves, mapping of the curve types, pseudosections, geoelectrical sections or profiles, and lithological models. 


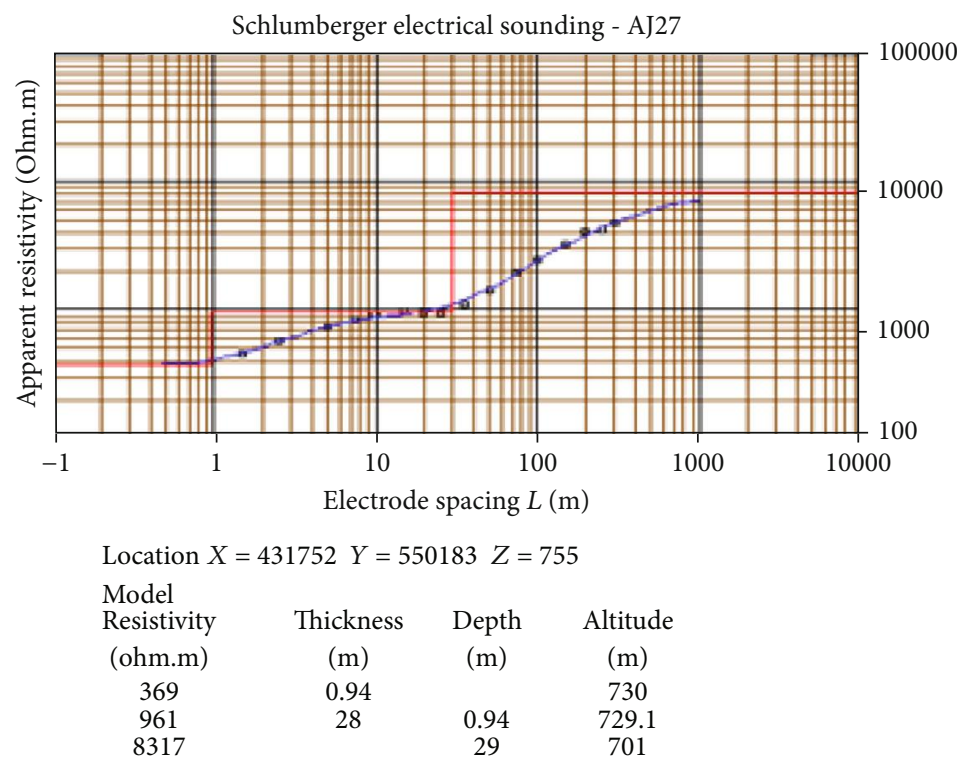

Figure 7: Sounding curves $\left(\mathrm{AJ}_{27}\right)$ of type A.

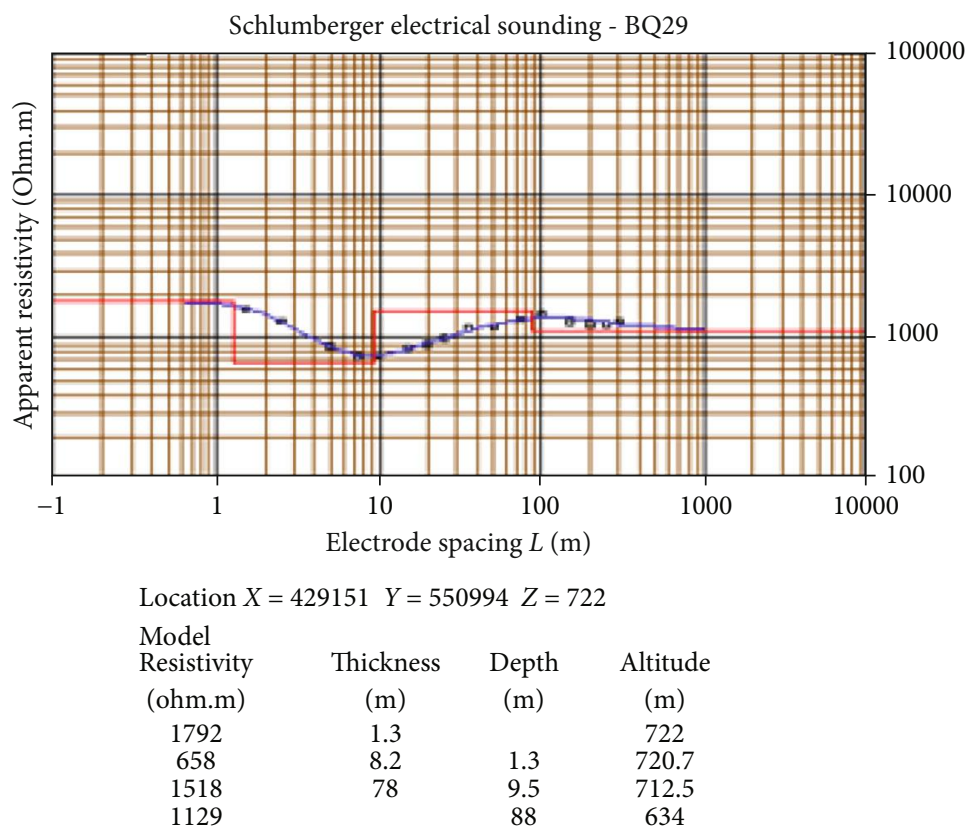

Figure 8: Sounding curve $\left(\mathrm{BQ}_{29}\right)$ of type $\mathrm{HK}$.

6.1. Typology of Sounding Curves. A total of nine hundred and seventy-six (976) electrical soundings were performed, including sixteen (16) parametric soundings. The study area is dominated by granitic formations and the tectonic setting shows that the area had been compressed between two blocks. After, this compressive tectonism created fractures and shear zones capable of modifying electrical conductivity of geologic formations [38]. In the study area, the main directions of strains are N-S and ENE-WSW [16]. Thus, in order to have the best knowledge of the resistivity values following a particular layer and to reduce anisotropic effects [37], profiles of sounding surveys were E-W and NNW-SSE oriented mainly (Figures 1(a) and 1(b)). In reality, geological formations are far from being isotropic. This is especially true of shale and clay formations. In clay, for example, the resistivity is the same in all directions along a layer but has a different value perpendicularly to the stratification. It therefore shows that, if resistivity is measured in the field with an array oriented characteristic parallel to the bedding planes, the measured resistivity is higher than the longitudinal resistivity by a ratio $\alpha$ [39]. 


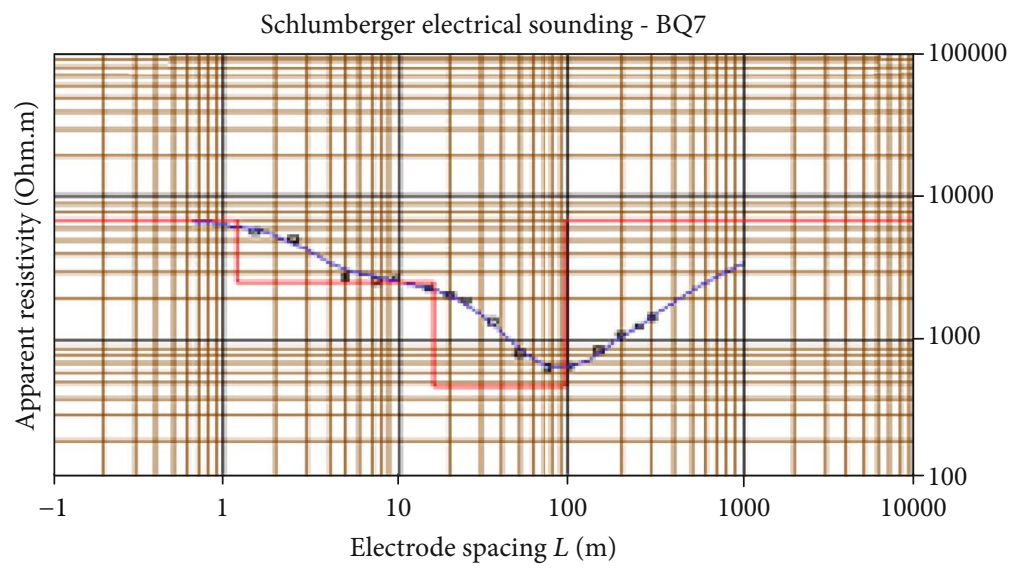

\begin{tabular}{|c|c|c|c|}
\hline \multicolumn{4}{|c|}{ Location $X=431351 \quad Y=550998 \quad Z=755$} \\
\hline $\begin{array}{l}\text { Model } \\
\text { Resistivity } \\
\text { (ohm.m) }\end{array}$ & $\begin{array}{l}\text { Thickness } \\
\text { (m) }\end{array}$ & $\begin{array}{l}\text { Depth } \\
(\mathrm{m})\end{array}$ & $\begin{array}{l}\text { Altitude } \\
(\mathrm{m})\end{array}$ \\
\hline 6911 & 1.2 & & 755 \\
\hline 2566 & 15 & 1.2 & 753.8 \\
\hline 477 & 77 & 16 & 739 \\
\hline 6967 & & 93 & 652 \\
\hline
\end{tabular}

10

(a)

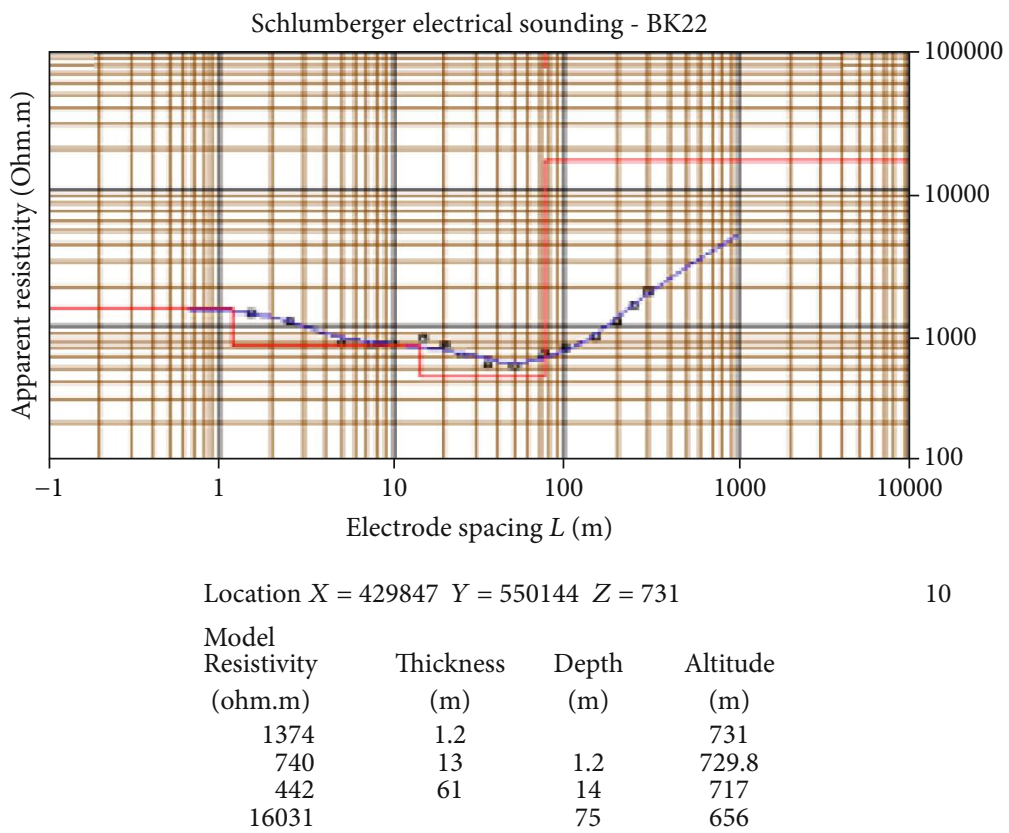

(b)

Figure 9: $(\mathrm{a}, \mathrm{b})$ Sounding curves $\left(\mathrm{BQ}_{7}\right.$ and $\left.\mathrm{BK}_{22}\right)$ of type $\mathrm{QH}$.

The processing, modelling, and interpretation of electrical data were performed with Geosoft's WinSev 6.4 software. This software does not show the scale of residual adjustment errors. They are not valid for superposed curves of different electrical soundings [31]. The scale begins always at $1 \%$ and has the same progression as the resistivity scale. Focusing only on interpretative soundings, eight (08) types of sounding curves (Figures 5-14) corresponding to particular geological arrangements have been highlighted. Based on previous works $[1,25,27-30,40,41]$ and field geological data, inter- pretative soundings enabled to characterize the typology of sounding curves of the study area and then to deduce a synthesis of the distribution of thicknesses $\left(e_{p}\right)$ and true resistivity values $(\rho)$ of geological layers from different sounding curves types. The red curves in the Schlumberger electrical sounding curves (Figures 5-14) characterize the distribution of thicknesses $\left(e_{p}\right)$ and true resistivity values $(\rho)$ of geological layers in the study area. They represent the results of $1 \mathrm{D}$ inversions of the apparent resistivity as a function of depth through Schlumberger electrical soundings [31]. The 1D 


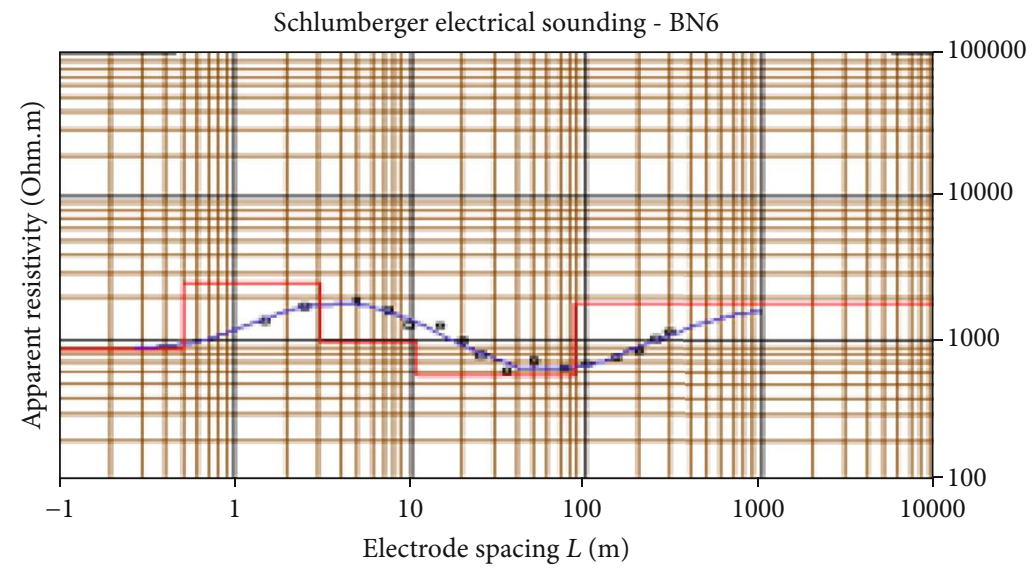

\begin{tabular}{|c|c|c|c|}
\hline $\begin{array}{l}\text { Model } \\
\text { Resistivity }\end{array}$ & Thickness & Depth & Altitude \\
\hline (ohm.m) & (m) & $(\mathrm{m})$ & (m) \\
\hline 862 & 0.52 & & 752 \\
\hline 2489 & 2.6 & 0.52 & 751.5 \\
\hline 985 & 7.9 & 3.1 & 748.9 \\
\hline 558 & 73 & 11 & 741 \\
\hline 558 & & 84 & 668 \\
\hline
\end{tabular}

(a)

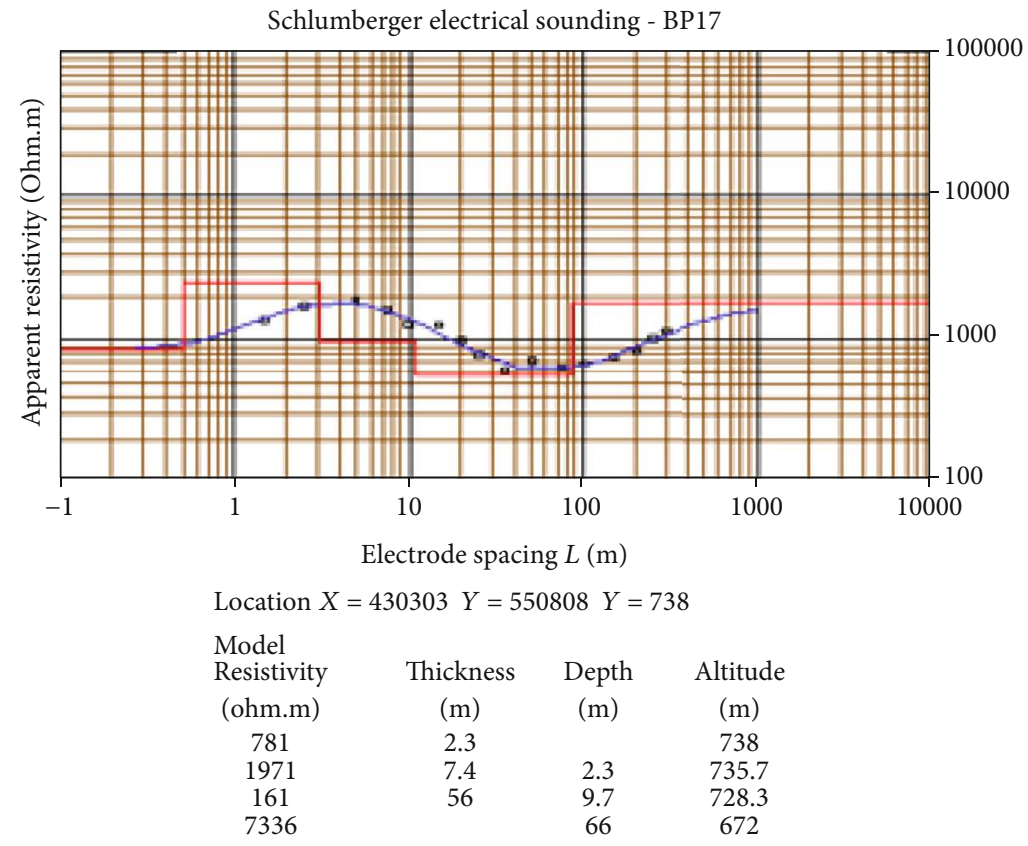

(b)

Figure 10: $(\mathrm{a}, \mathrm{b})$ Sounding curves $\left(\mathrm{BN}_{6}\right.$ and $\left.\mathrm{BP}_{17}\right)$ of type $\mathrm{KH}$.

inversion using Winsev software is used for the calculation of the theoretical curve [31] following the method described by Koefoed [32]. It permits to have the blue curves (Figures 514) which correlate with the experimental points perfectly (Figures 5-14). This correlation minimizes the errors of 1D models given by red curves.

6.2. Mapping of the Curve Types. The mapping of the curve types shows the characteristics of the horizontal variety of layers in the studied areas. Figure 15 shows the mapping of the electrical sounding curve types in the Colomine area (Figure 1(a)). This mapping presents along the horizontal line the curve types identified which ranges from $G, H, A$, $\mathrm{QH}, \mathrm{KH}, \mathrm{HK}, \mathrm{HA}, \mathrm{HKH}$, to $\mathrm{KHK}$ and shows the variety of structures along the studied profiles.

6.3. Characteristic of the Curve Types. Curves types identified ranges from $\mathrm{G}, \mathrm{H}, \mathrm{A}, \mathrm{QH}, \mathrm{KH}, \mathrm{HK}, \mathrm{HA}, \mathrm{HKH}$, to KHK varying between two to five geoelectric layers. In the Colomine locality (Figure 1(a)), the $\mathrm{H}$ and $\mathrm{KH}$ curve types dominate, 


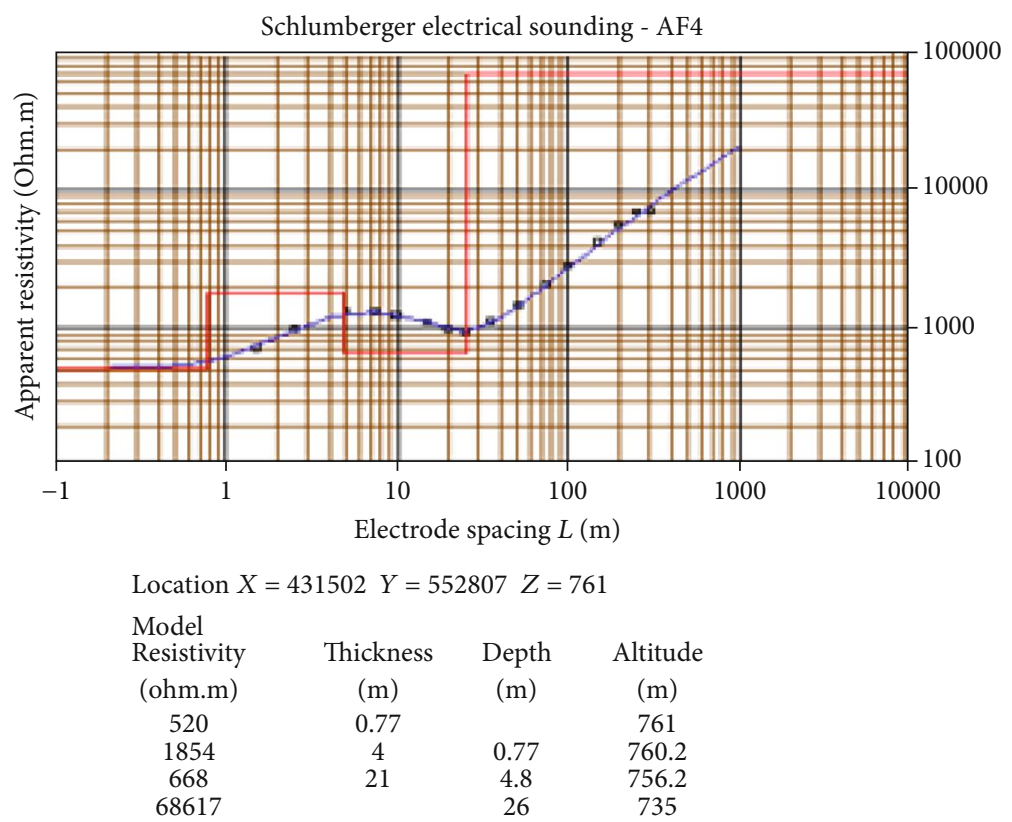

(a)

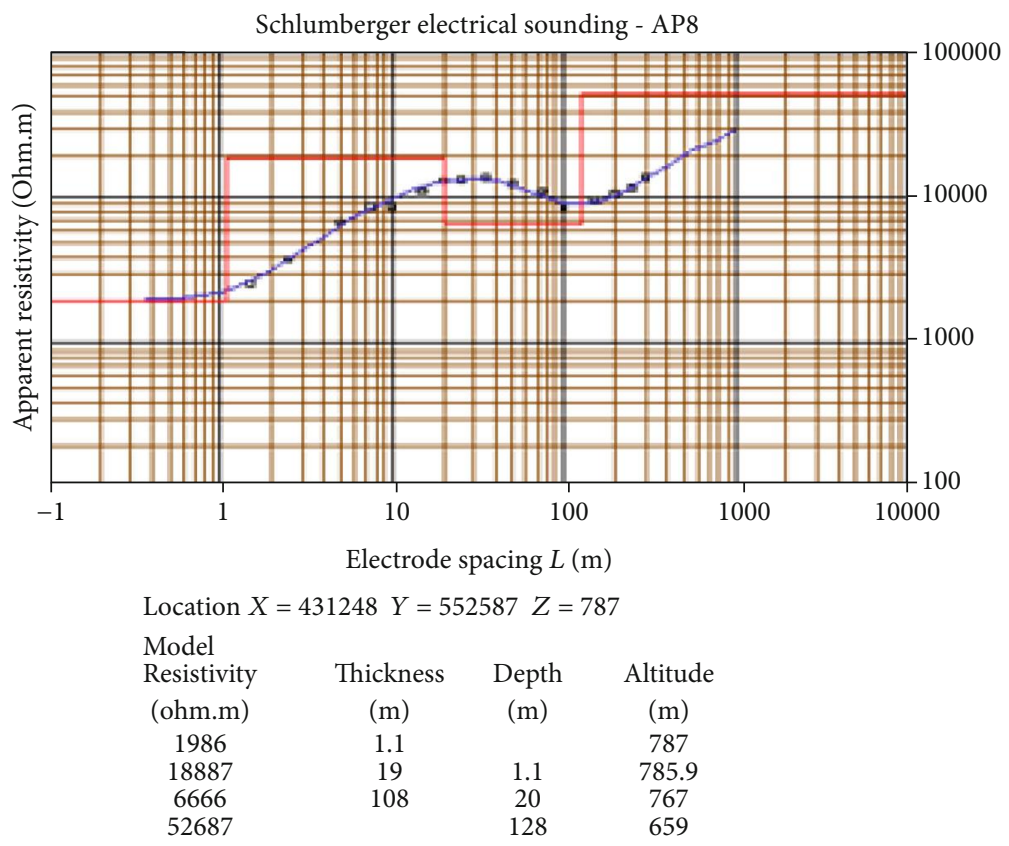

(b)

Figure 11: $(\mathrm{a}, \mathrm{b})$ Sounding curves $\left(\mathrm{AF}_{4}\right.$ and $\left.\mathrm{AP}_{8}\right)$ of type KH.

constituting $45.5 \%$ and $20.9 \%$ of the total, while the $\mathrm{QH}$, $\mathrm{HKH}, \mathrm{G}, \mathrm{HA}, \mathrm{A}, \mathrm{HK}$, and KHK types constitute $8.9 \%, 7 \%$, $6.6 \%, 5 \%, 3.3 \%, 1.8$ and $1 \%$, respectively (Figure 16).

6.4. Pseudosections. The pseudosection is the inversion of apparent resistivity following horizontal and vertical lines. It reflects the resistivity distribution versus electrode spacing values $(\mathrm{AB} / 2)$ and shows the electrical characteristic of layers following horizontal and vertical lines. Along pseudosections (Figures 17(a) and 17(b)), the resistivity varies in depth and following the horizontal line, and then we note the vertical and horizontal changes of layers. These changes characterize a diversity of geological structures in depth and along the horizontal line and therefore attest the diversity of observed curve types. Generally, in the pseudosections of the study area, maximum resistivity values appeared in the upper parts because of the dry alluvium or of the presence of basement in the subsurface. They decreased toward the middle parts because of the influence of a conductive discontinuity or of an aquifer then increased with depth because of the resistant basement. In Figure 12, the pseudosection of L11 is shown as an example. In Figure 14, flanks of the pseudosection were lower than the central part because of the influence 


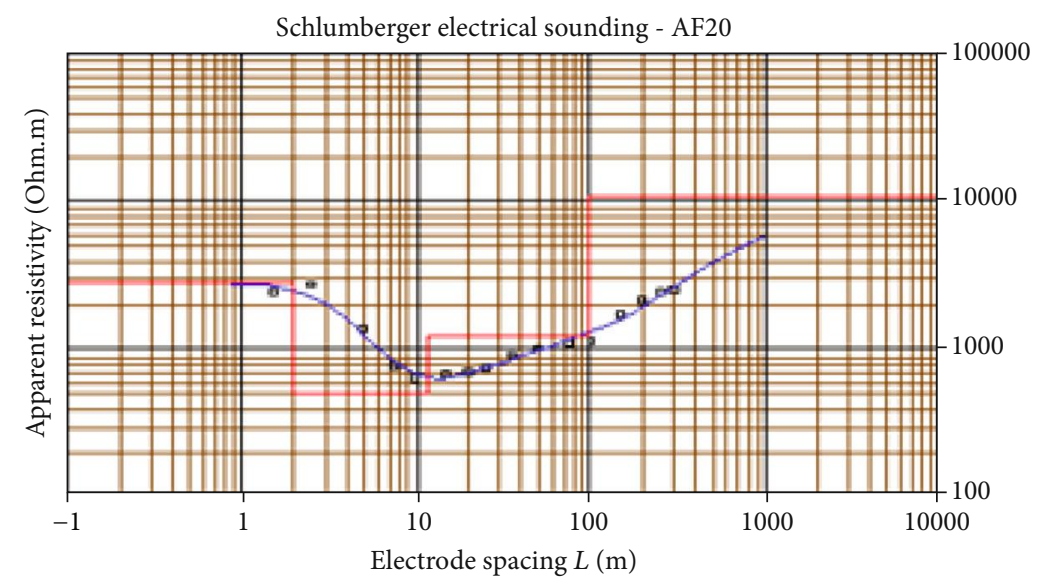

\begin{tabular}{|c|c|c|c|}
\hline $\begin{array}{l}\text { Model } \\
\text { Resistivity } \\
\text { (ohm.m) }\end{array}$ & $\begin{array}{l}\text { Thickness } \\
\text { (m) }\end{array}$ & $\begin{array}{l}\text { Depth } \\
\text { (m) }\end{array}$ & $\begin{array}{l}\text { Altitude } \\
\text { (m) }\end{array}$ \\
\hline 2851 & 2 & & 735 \\
\hline 513 & 9.8 & 2 & 733 \\
\hline 1262 & 88 & 12 & 723 \\
\hline 10887 & & 100 & 635 \\
\hline
\end{tabular}

FIGURE 12: Sounding curve $\left(\mathrm{AF}_{20}\right)$ of type HA.

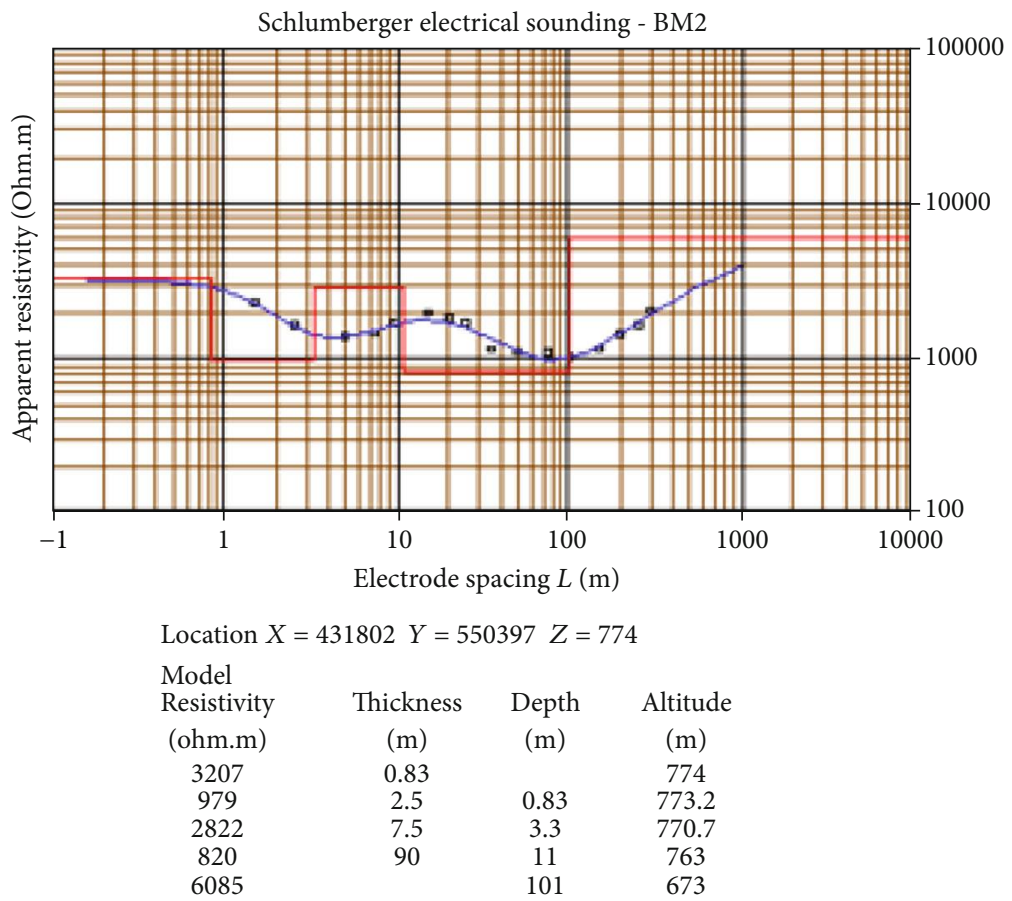

FIGURE 13: Sounding curve $\left(\mathrm{BM}_{2}\right)$ of type HKH.

of a conductive discontinuity or of an aquifer and the coarse grain size dry alluvium or basement structures along the central part.

6.5. Geoelectrical and Lithological Sections of the Sounding Curves. The vertical electrical sounding interpretation results in the study areas were used to prepare 2D geoelectric sections or geoelectrical profiles. The $2 \mathrm{D}$ geoelectric sections show the vertical and horizontal changes of layers along profiles in the underground until $120 \mathrm{~m}$ depth. The 2D geoelectric sections along profiles L10 and L11 (Figures 18(a) and 18 (b)) are shown as examples. We note a diversity of $1 \mathrm{D}$ geoelectric models following the horizontal line and the vertical changes of layers in depth. In the studied areas, the $2 \mathrm{D}$ geoelectric sections identified vary between two to five geoelectric layers. 


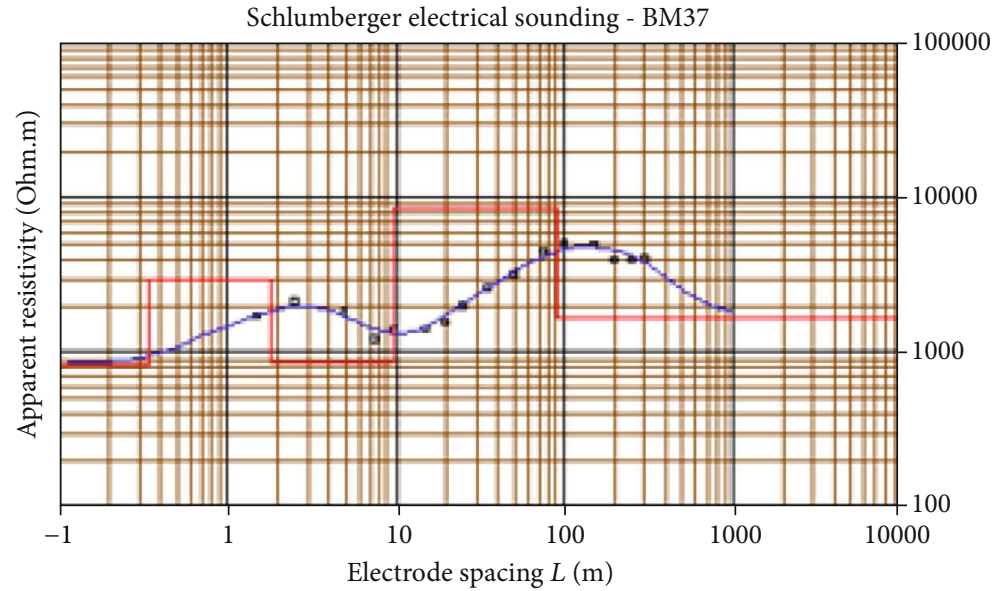

Location $X=428303 \quad Y=550326 Z=723$

Model

Resistivity Thickness Depth Altitude

$\begin{array}{cccc}\text { (ohm.m) } & (\mathrm{m}) & (\mathrm{m}) & (\mathrm{m}) \\ 847 & 0.34 & & 723 \\ 2986 & 1.5 & 0.34 & 722.7 \\ 875 & 7.8 & 1.8 & 721.2 \\ 8337 & 81 & 9.6 & 713.4 \\ 1702 & & 91 & 632\end{array}$

FIGURE 14: Sounding curve $\left(\mathrm{BM}_{37}\right)$ of type KHK.

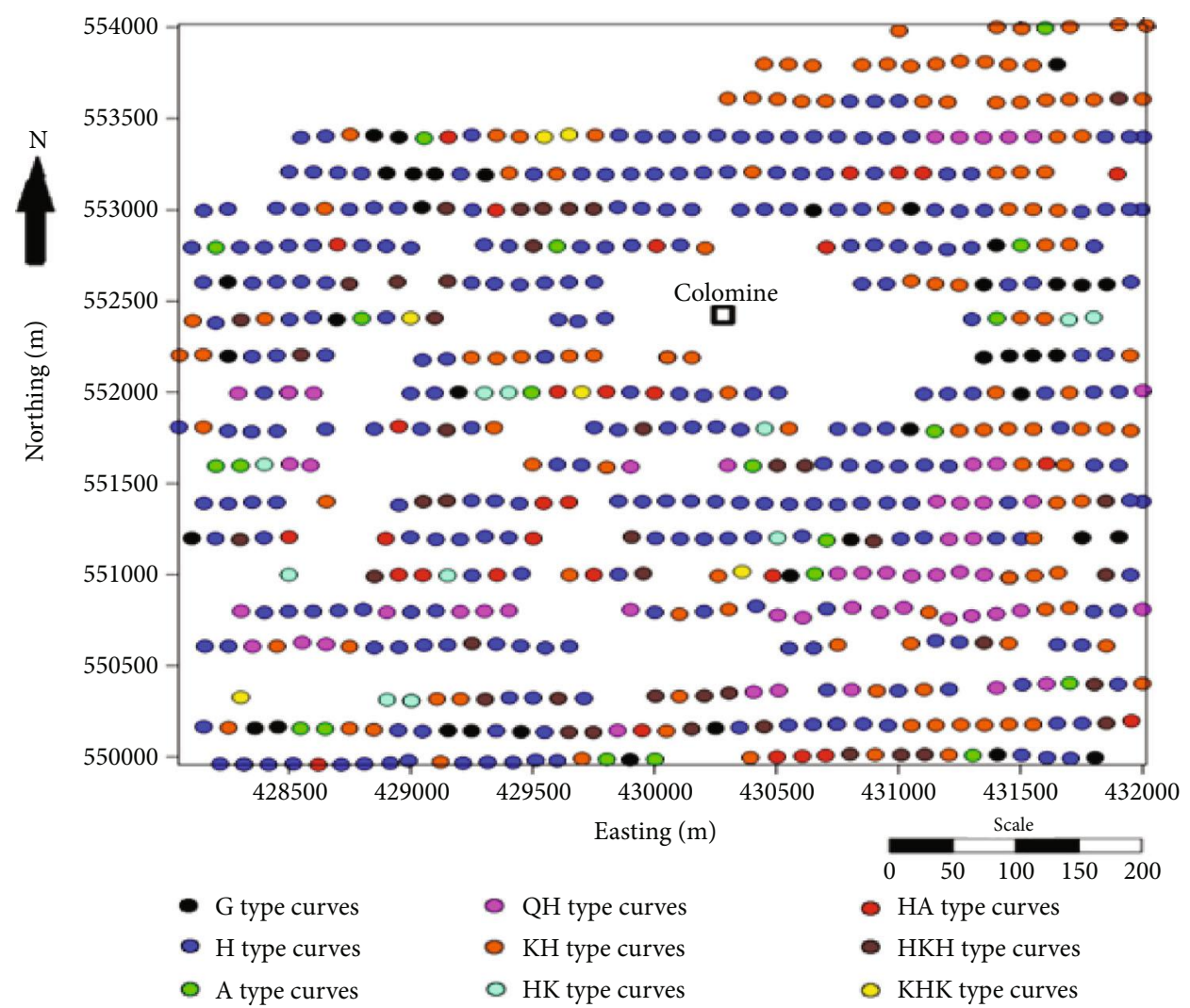

Figure 15: Map of curve types of the Colomine area.

Results from the vertical electrical soundings using the Borreguero and Jenny program show evidences of several electrical sounding curve types $(\mathrm{H}, \mathrm{A}, \mathrm{QH}, \mathrm{KH}, \mathrm{HK}, \mathrm{HA}$,
$\mathrm{HKH}$, and KHK). Each curve type defines a geological bedding model of the surveyed subsurface. The electrical characteristics of geological layers (resistivity $\rho$ and 


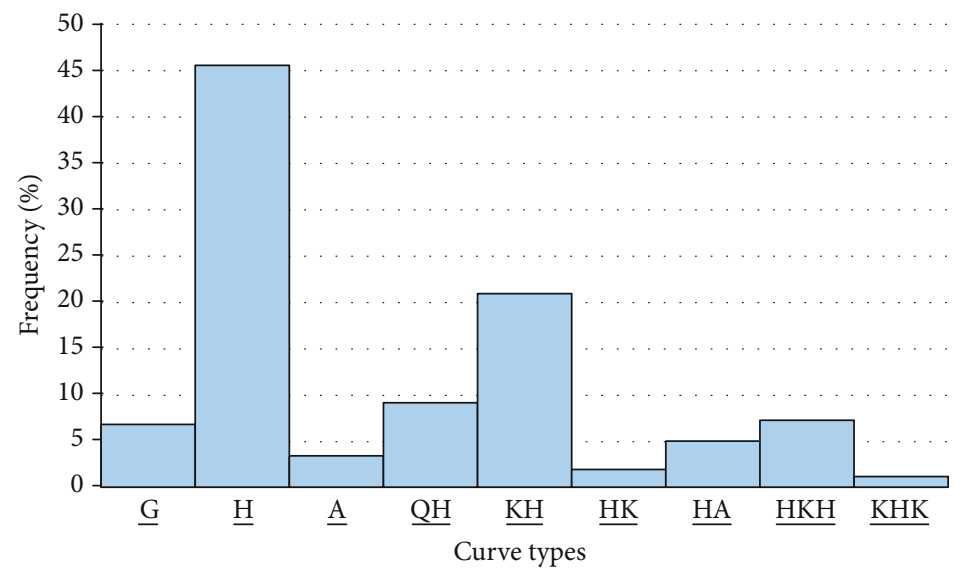

Figure 16: Histogram of the curve types in the Colomine area.

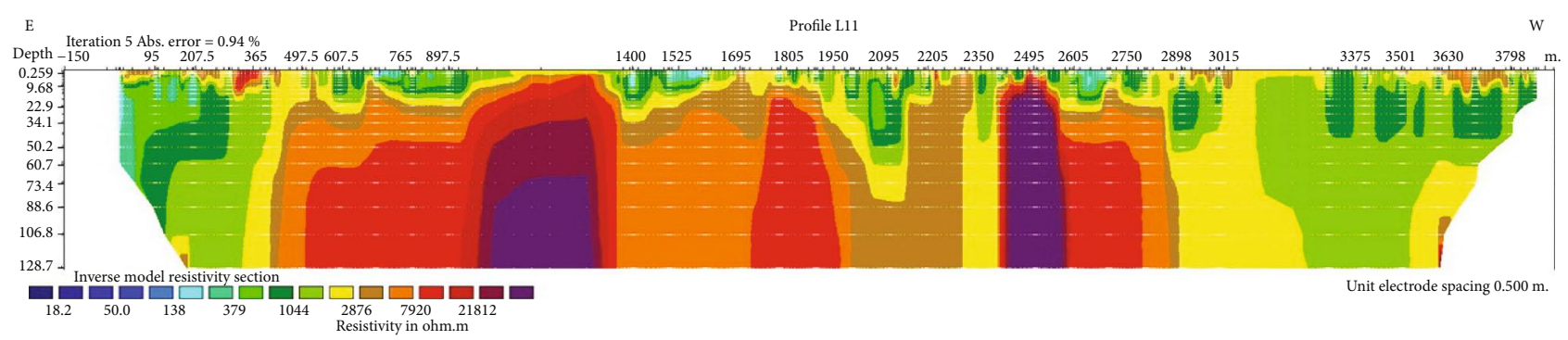

(a)

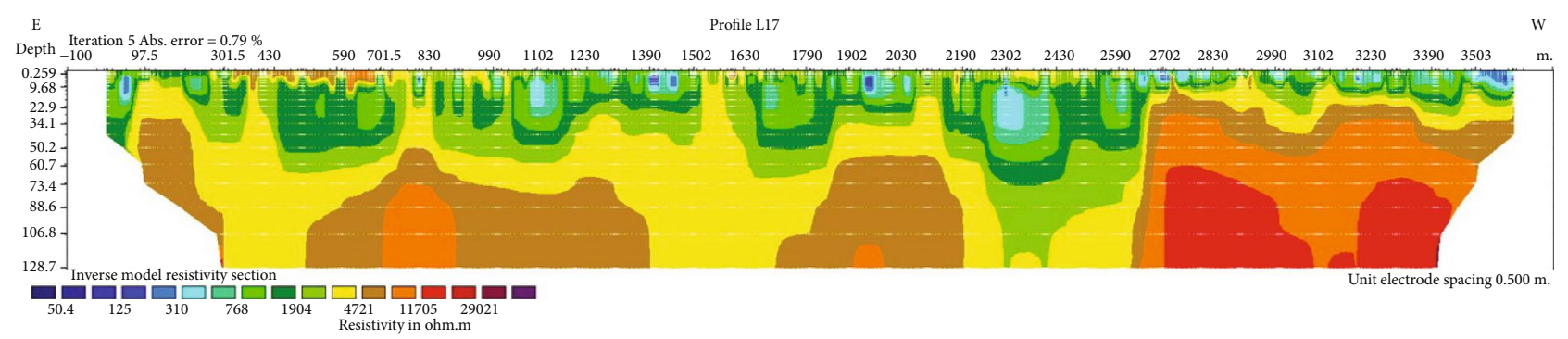

(b)

Figure 17: (a) Geolectrical pseudosection of profile L11 (Colomine area 1). (b) Geolectrical pseudosection of profile L17 (Colomine area 1).

thickness $e_{p}$ ) obtained from the $1 \mathrm{D}$ inversion of measured geoelectrical data, the geological exploration on outcrops, and in gold mining pits (Figure 2(b)), and from previous studies of Palacky [42], Akpabio and Ekpo [43], Oladapo et al. [44], Alile et al. [45], Raimi et al. [29], and Coker [27], help to plot geoelectrical models for the subsurface derived from the different types of electrical sounding curves produced (Figures 5-14). The geoelectrical models provide lithological 1D models for the crystalline basements in the Batouri and Ngoura subdivisions. It permits to characterize normal (the resistivity increases in depth (e.g., $\rho_{1}$ $<\rho_{2}<\rho_{3}$ )) or abnormal (we note a decrease of the resistivity in depth (e.g., $\left.\rho_{1}<\rho_{2}>\rho_{3}<\rho_{4}\right)$ ) distribution of the electric properties of layers $[24,30,38]$. The lithological $1 \mathrm{D}$ model of an abnormal distribution of the electric properties of layers is well in the mineral and groundwater prospecting within crystalline basement rocks [24, 30, 38].
The G-type $\left(\rho_{1}<\rho_{2}\right)$, H-type $\left(\rho_{1}>\rho_{2}<\rho_{3}\right)$, and Atype $\left(\rho_{1}<\rho_{2}<\rho_{3}\right)$ sounding curves were illustrated by the $\mathrm{BE}_{10}, \mathrm{BK}_{3}$, and $\mathrm{AJ}_{27}$ sounding curves (Figures 5-7), respectively. They characterize lateritic levels ( $G$ and $H$ types) and a weathered or fractured bedrock overlain by a thin overburden (A type). The general interpretation states two- and three-layered earth models. Lateritic recovering represents the most superficial and first layer $\left(1<e_{p 1}<20 \mathrm{~m} ; 600<\rho_{1}<3000 \Omega\right.$.m). The second layer for $\mathrm{H}$ and $\mathrm{A}$ types represents the conductive layer and the fractured/weathered granite, respectively. It is characterized by a lower resistivity $\left(100<\rho_{2}<1000 \Omega\right.$.m and $\left.600<\rho_{2}<2000 \Omega . \mathrm{m}\right)$ with thickness varying from $10 \mathrm{~m}$ to $110 \mathrm{~m}$. The last layer ( $\mathrm{G}, \mathrm{H}$, and A types) corresponds to the resistive basement $\left(\rho_{2}\right.$ or $\left.\rho_{3}>2500 \Omega . \mathrm{m}\right)$. The above interpretation enables the realisation of geoelectrical loggings and to define lithological models of the 


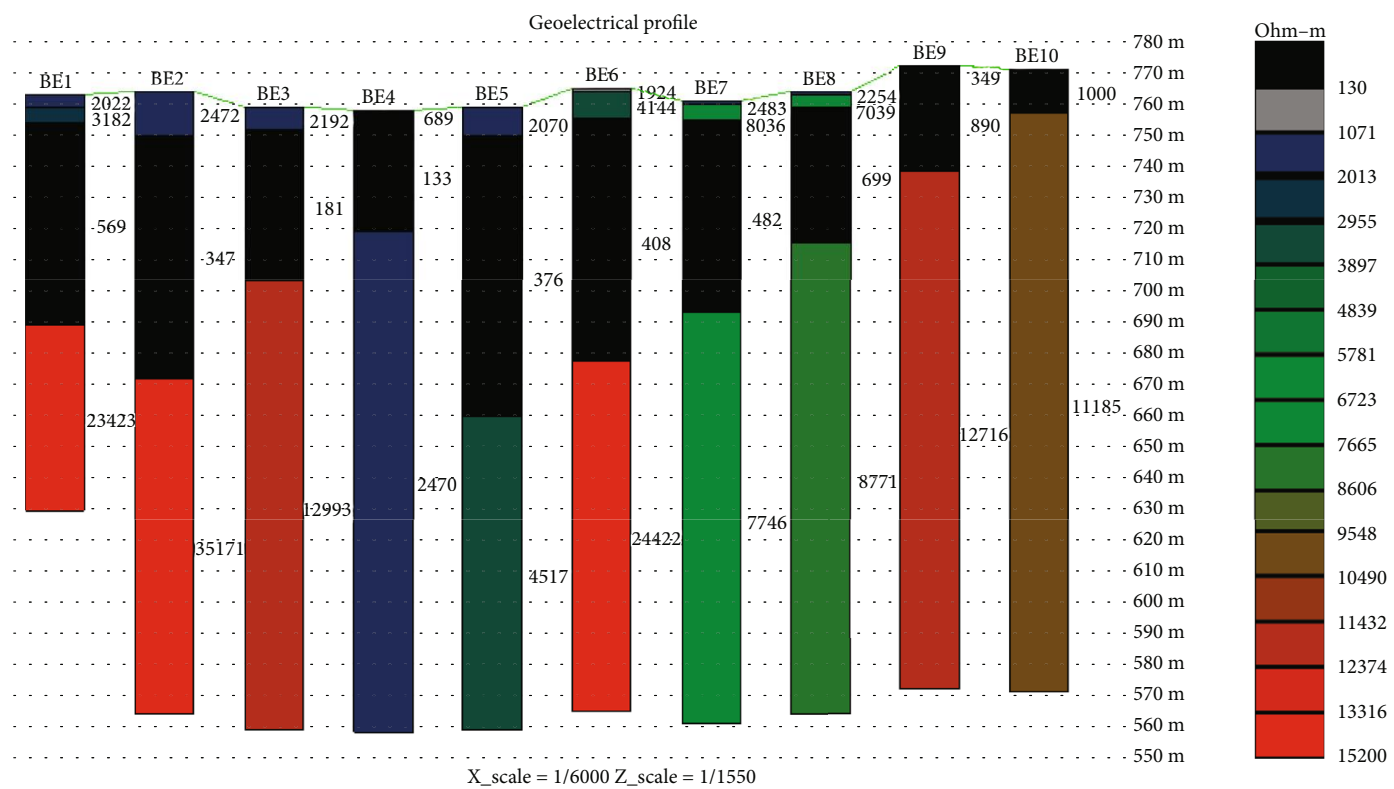

(a)

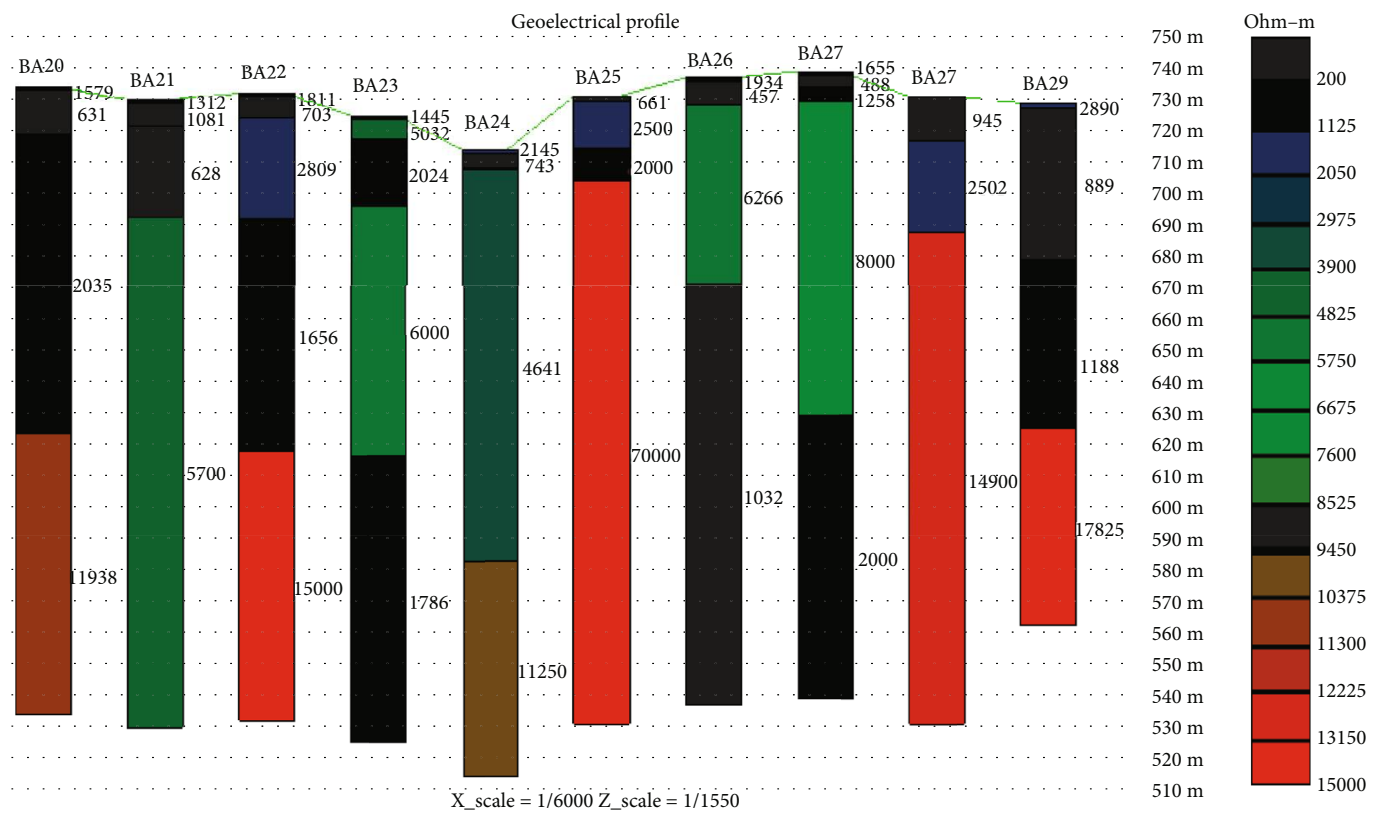

(b)

Figure 18: (a) Geoelectrical section of profile L10 (Colomine, area 1). b. Geoelectrical section of profile L11 (Colomine, area 1).

investigated subsurface (Figures 19-21). The lithological models of sounding curves $G$ and A types present normal distributions in depth of the electric properties of layers, while the lithological model of sounding curves of $\mathrm{H}$ type present an abnormal distribution in depth of the electric properties of layers.

The HK-type $\left(\rho_{1}>\rho_{2}<\rho_{3}>\rho_{4}\right), \quad$ QH-type $\left(\rho_{1}>\rho_{2}>\rho_{3}<\rho_{4}\right)$, KH-type $\left(\rho_{1}<\rho_{2}>\rho_{3}<\rho_{4}\right)$, and HAtype $\left(\rho_{1}>\rho_{2}<\rho_{3}<\rho_{4}\right)$ sounding curves were illustrated by $\mathrm{BQ}_{7}$ and $\mathrm{BK}_{22} ; \mathrm{BN}_{6}, \mathrm{BP}_{17}, \mathrm{AF}_{4}$, and $\mathrm{AP}_{8} ; \mathrm{BQ}_{29} ;$ and $\mathrm{AF}_{20}$ sounding curves (Figures 8-12), respectively. They characterize conductive layer intrusion (Figure 8), lateritic hardpan in high altitude (Figure 9(a)) and low altitude (Figure 9(b)) areas, megafractures occurrences (Figures 10 and 12), and the involvement of a weathered quartz vein (Figure 11(a)) within basement formations and fractured basement (Figure 11(b)). The first layer corresponds to a thin laterite or a mixture of sandy and lateritic soil $\left(1<e_{p 1}<2 \mathrm{~m}\right.$; $\left.4000<\rho_{1}<10000 \Omega . \mathrm{m}\right)$. The second layer corresponds to a relatively thick lateritic layer, a regolith granitic or a conductive level $\left(10<e_{p 2}<20 \mathrm{~m} ; 1500<\rho_{2}<4000 \Omega\right.$.m $)$. The third layer characterizes a conductive layer or a thin or thick highly fractured and/or weathered granite $\left(50<e_{p 3}<100 \mathrm{~m} ; \quad 100<\rho_{3}<1000 \Omega . \mathrm{m}\right)$ and the last 


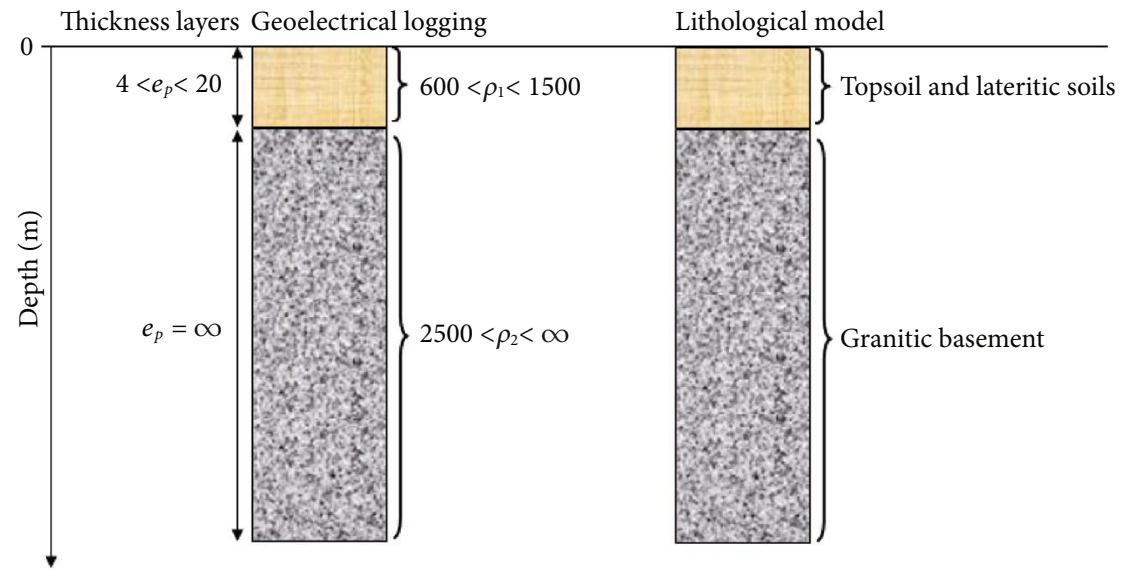

FIGURE 19: Lithological model of sounding curves of type G.

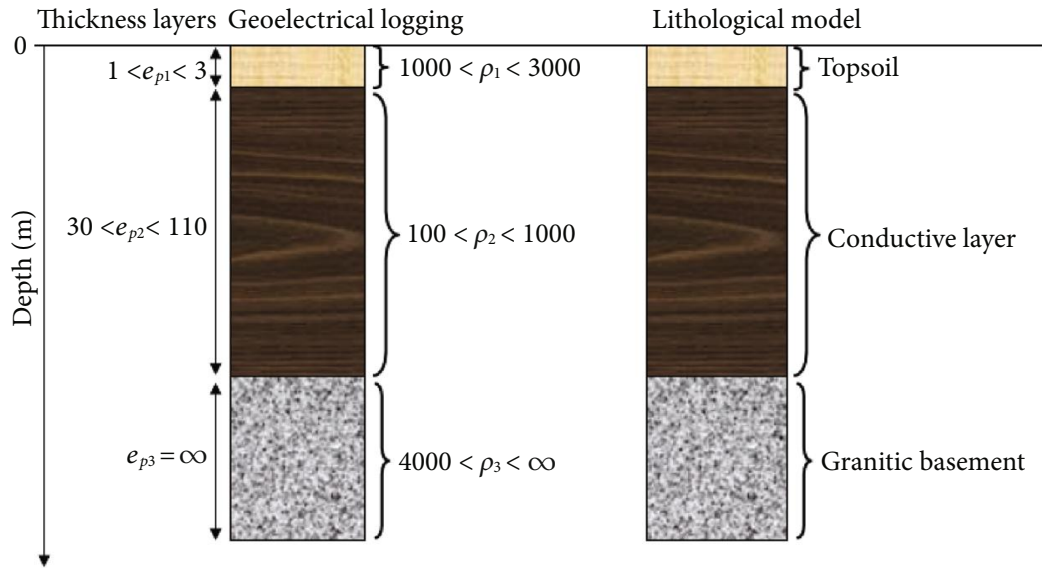

Figure 20: Lithological model of sounding curves of type $H$.

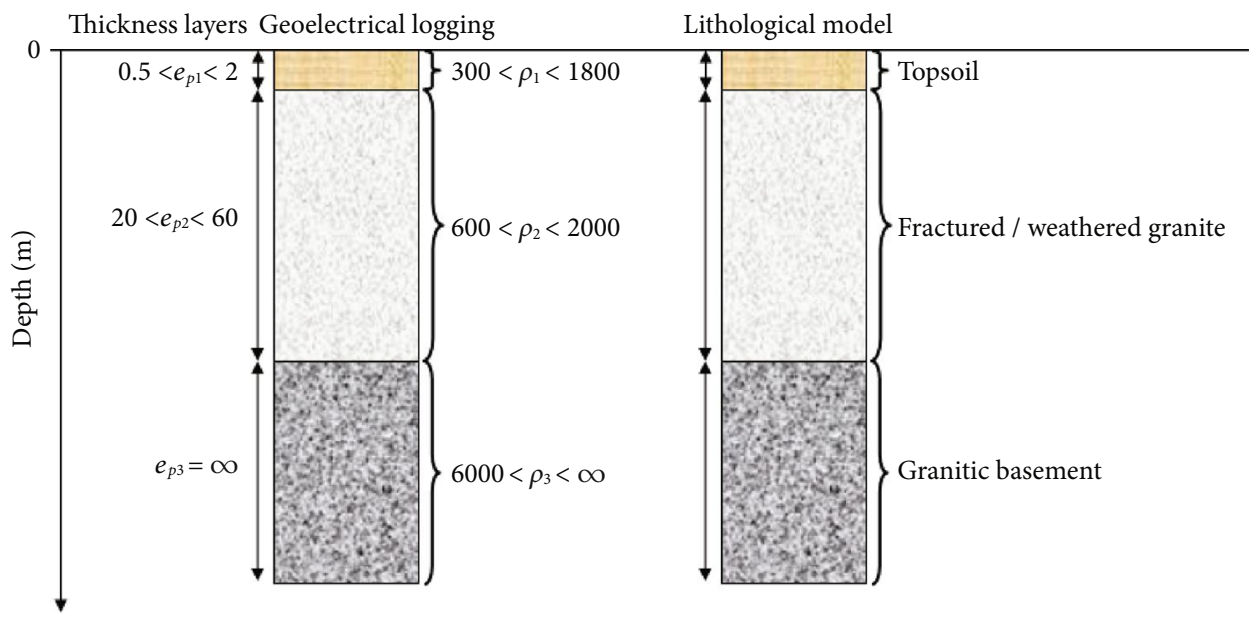

FIgure 21: Lithological models of the sounding curves of type A.

corresponds to a less or highly fractured granitic basement $\left(\rho_{4}>4000 \Omega\right.$.m). The above interpretation enables the realisation of geoelectrical loggings and to define lithological models of the investigated subsurface (Figures 22-25). The lithological models of sounding curves of $\mathrm{QH}, \mathrm{HK}$, and
HA types present abnormal distributions in depth of the electric properties of layers.

The $\mathrm{BM}_{2}$ and $\mathrm{BM}_{37}$ sounding curves (Figures 13 and 14) representing the HKH-type $\left(\rho_{1}>\rho_{2}<\rho_{3}>\rho_{4}<\rho_{5}\right)$ and KHK-type $\left(\rho_{1}<\rho_{2}>\rho_{3}<\rho_{4}>\rho_{5}\right)$ sounding curves, 


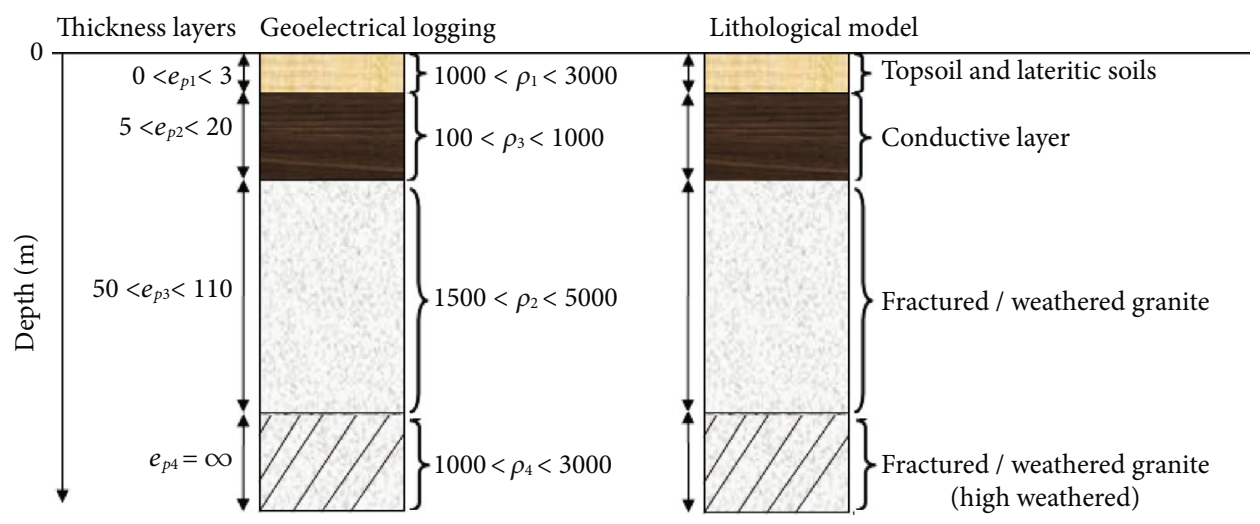

Figure 22: Lithological model of the sounding curves of type HK.

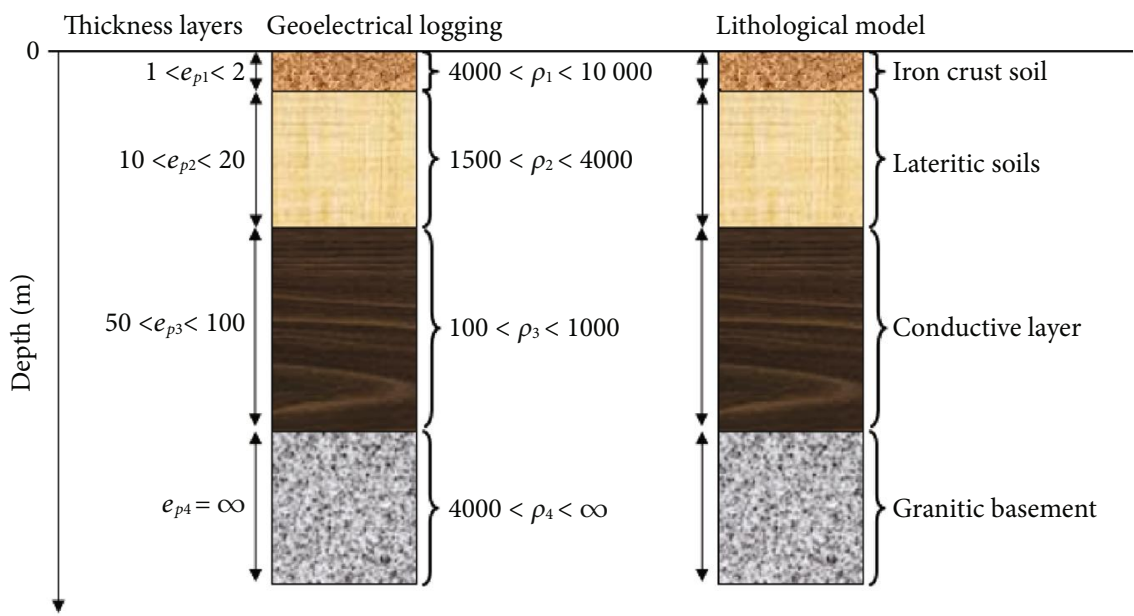

(a)

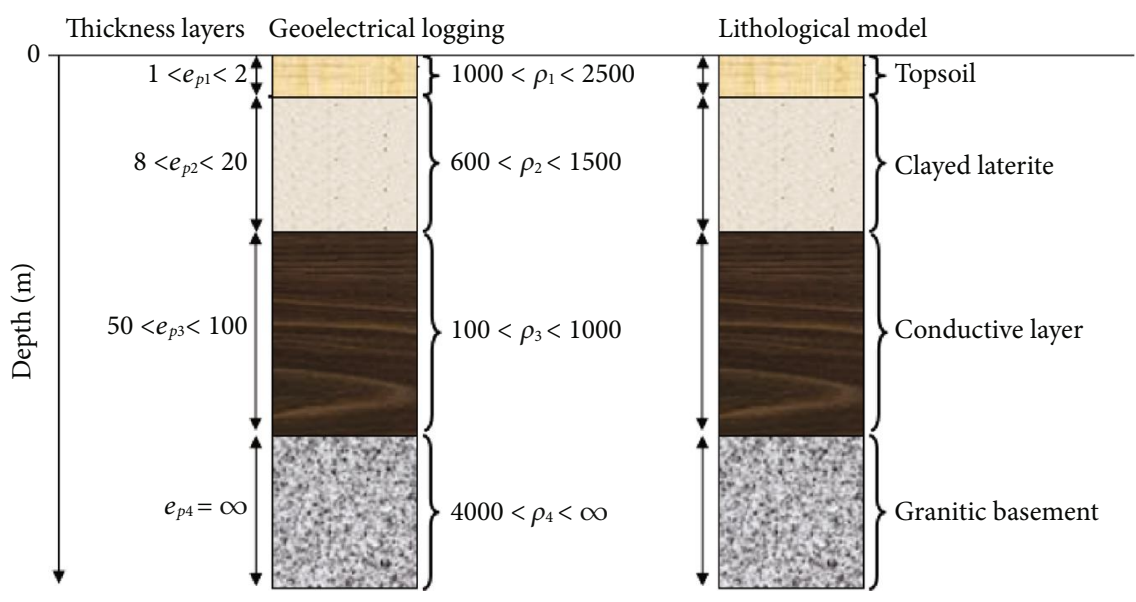

(b)

Figure 23: (a, b) Lithological models of sounding curves of type QH.

respectively, characterize two consecutive groundwater levels (two adjacent conductive layers or clayey sandy layers) in the hydrogeological survey (HKH-type) and a lateritic layer on thalwegs (KHK type). The HKH-type and KHK-type sounding curves suggest five-layered earth models with: the first being an overburden lateritic soil; the second and fourth, two clayey sandy conductive layers $\left(2<e_{p 2}<20 \mathrm{~m} ; 100<\rho_{2}<1000 \Omega . \mathrm{m}\right)$ for HKH-type and dry clayey laterites $\left(1<e_{p 2}<10 \mathrm{~m} ; 2000<\rho_{2}<4000 \Omega\right.$.m $)$ and the weakly weathered and fractured granitic rocks $\left(50<e_{p 4}<110 \mathrm{~m} ; 5000<\rho_{4}<10000 \Omega . \mathrm{m}\right) ;$ the third, dry clayey laterites $\left(5<e_{p 3}<20 \mathrm{~m} ; \quad 2000<\rho_{3}<3500 \Omega\right.$.m $)$ 


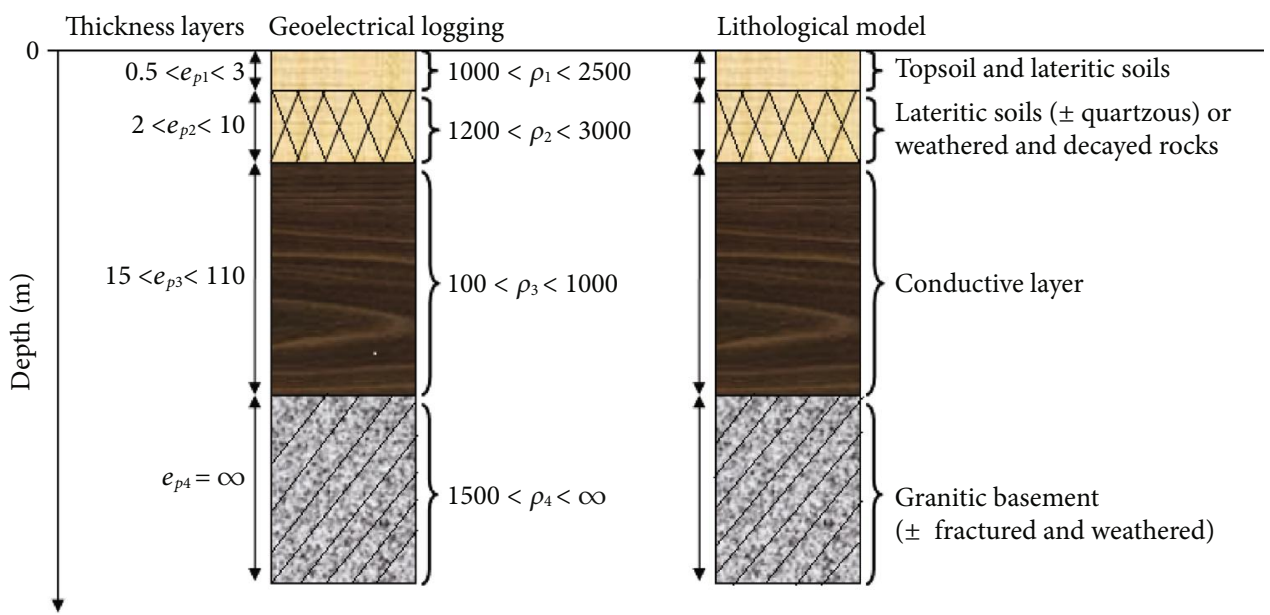

(a)

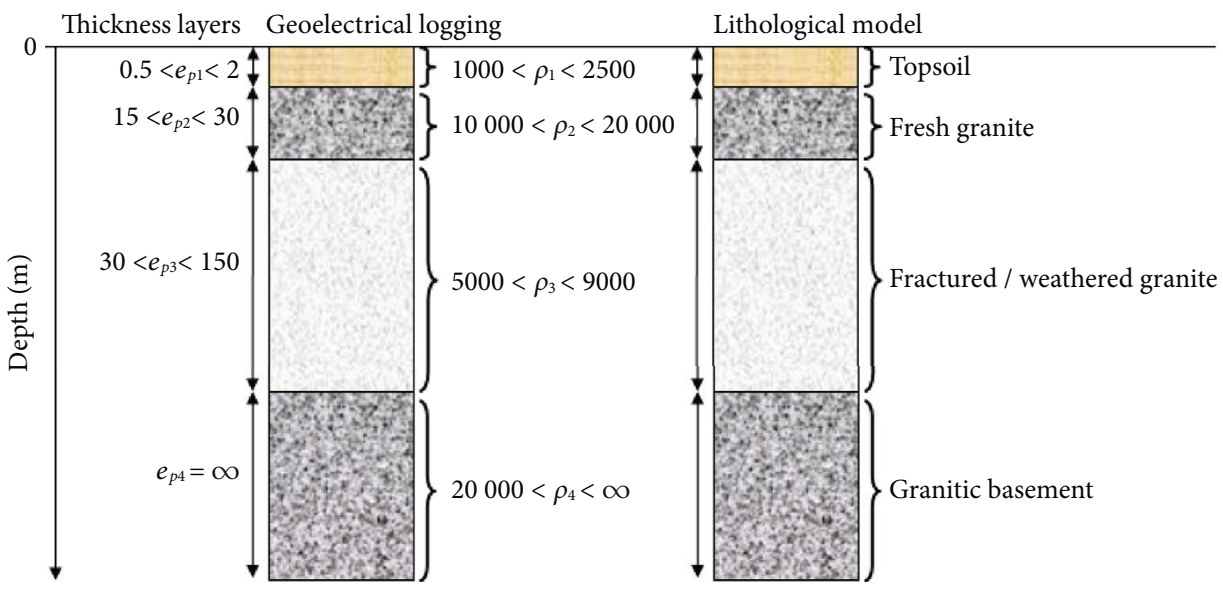

(b)

Figure 24: $(\mathrm{a}, \mathrm{b})$ Lithological models of the sounding curves of type $\mathrm{KH}$.

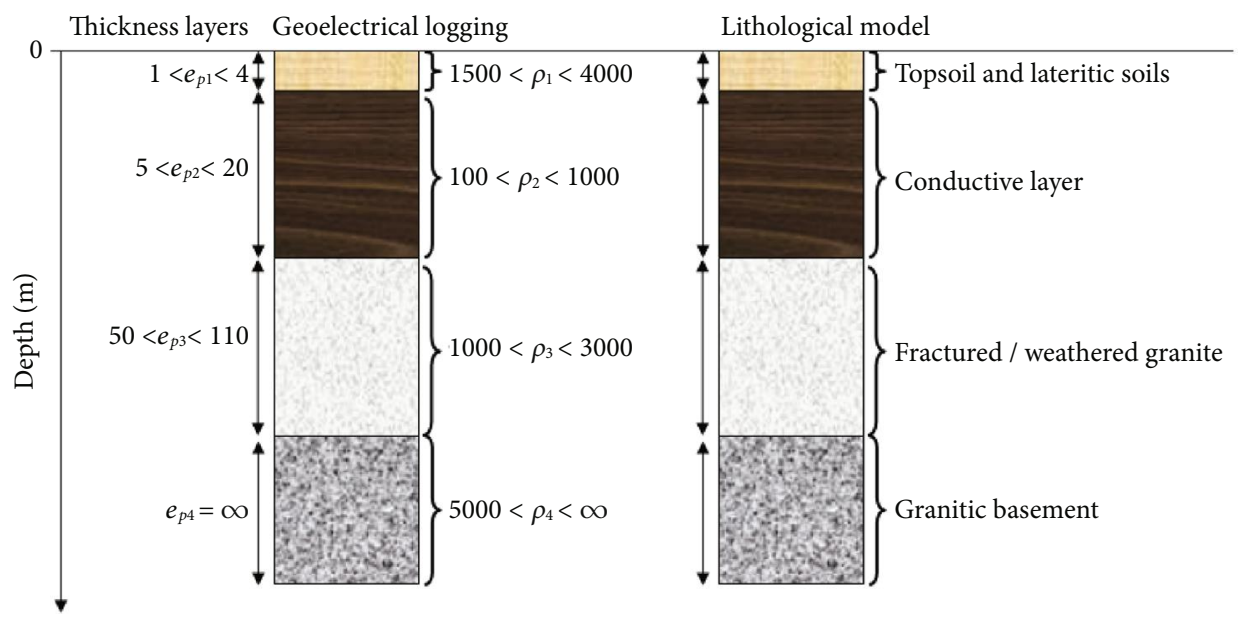

Figure 25: Lithological model of the sounding curves of type HA.

linking the two conductive layers for $\mathrm{HKH}$ type, while for KHK type, it represents the conductive level which correspond to the HA type in Figure 12. The last layer depicts the less fissured or fresh granitic basement for
$\mathrm{HKH}$ type, while for KHK type, it represents the highly altered and fractured granitic basement $\left(\rho_{5}<2000 \Omega . \mathrm{m}\right)$. The geoelectrical loggings were realised and lithological models were defined for the investigated subsurface 


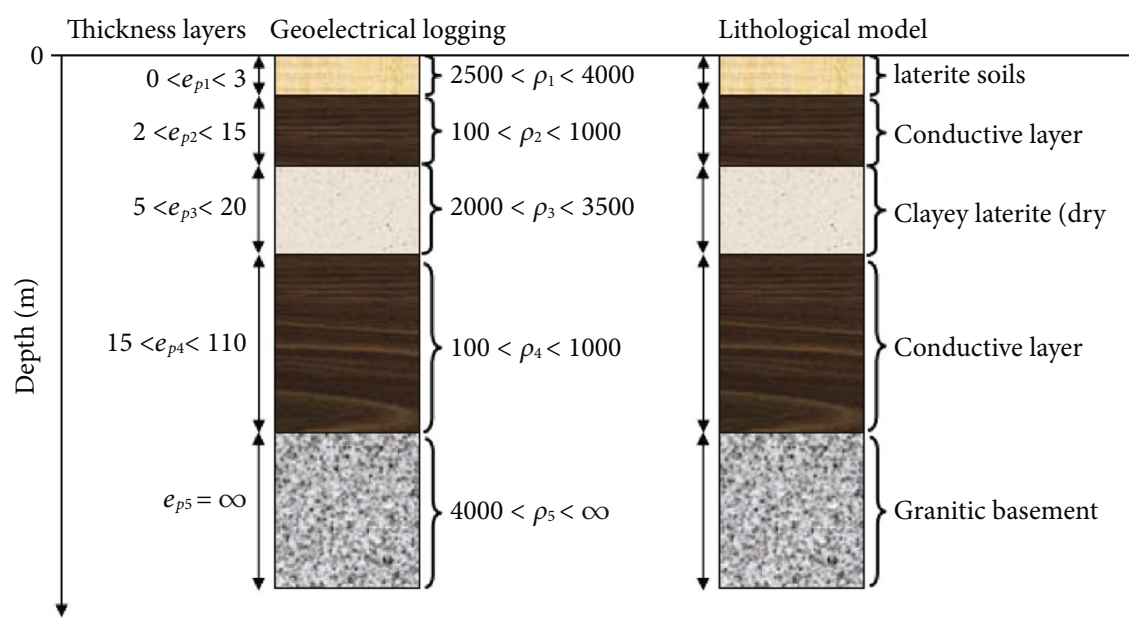

FIGURE 26: Lithological model of the sounding curves of type HKH.

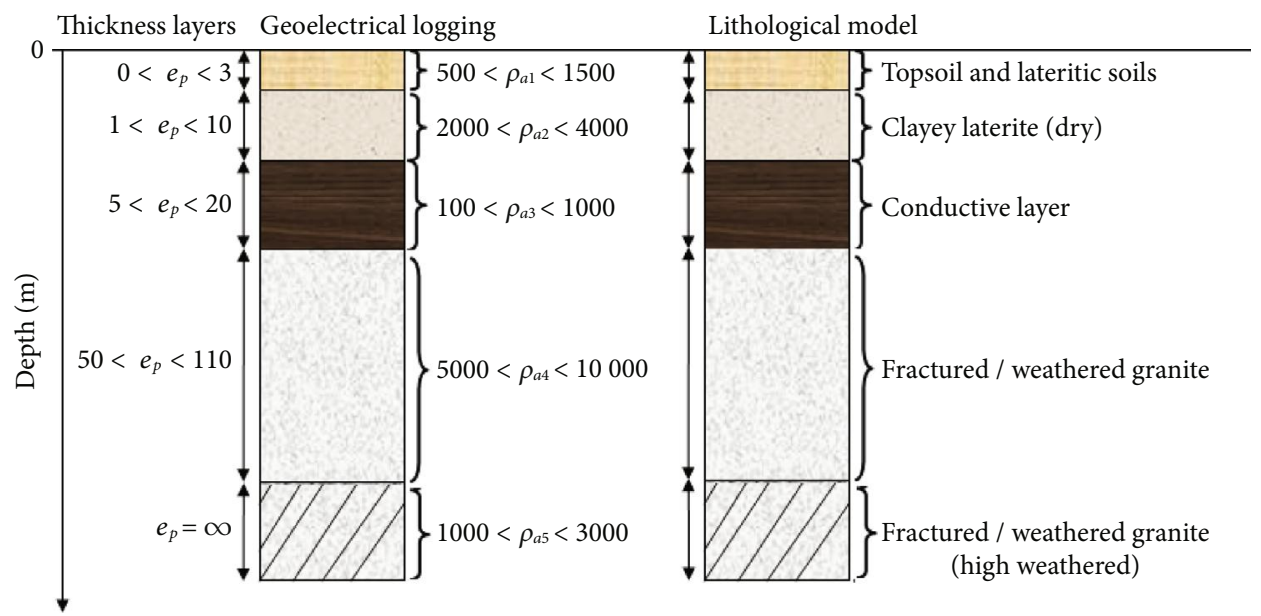

FIgURE 27: Lithological model of the sounding curves of type KHK.

(Figures 26 and 27). The lithological models of sounding curves of types $\mathrm{HKH}$ and $\mathrm{KHK}$ present abnormal distributions in depth of the electric properties of layers.

\section{Discussion}

Geophysical resistivity techniques are based on the response of the earth to the flow of electrical current. In the shallow subsurface, the presence of water controls much of the conductivity variation. Measurement of the resistivity is a measure of the amount of water saturation and connectivity of pore space. Increasing water content and increasing salinity of the underground water will decrease the measured resistivity. So, increasing porosity of rock and increasing number of fractures will tend to decrease measured resistivity if the voids are water filled [46]. The geophysical methods (VES) were applied in this study, not only to bring information about fresh water bodies in the underground but also information about the geological structure, fractures, and rupture zones in the underground until $120 \mathrm{~m}$ depth. By this VES method (Schlumberger sounding), the variation of the resistivity with depth is measured, depending on the electric properties of the geologic sequences in the subsurface [46]. The electric properties are influenced by the lithology, the water saturation degree of pore spaces, the salinity of the mineralogical fluids involved, and the mineralized bodies along the tectonic lines (fractures and rupture zones) [15, 46]. The electric properties of the geologic sequences in the studied subsurface characterize the horizontal and vertical resistivity distributions in the underground and shapes of the vertical electrical sounding curve types.

Measures of electric properties of the geologic sequences of the crystalline basements in Batouri and Ngoura subdivisions of nine hundred and seventy-six (976) Schlumberger electrical surveys and their 1D inversion enabled to propose a shape set of sounding curves. Nine (09) types of sounding curves (Figures 5-14) materializing the arrangement of geological layers are defined, as well as their electrical variation, based on Telford et al. [30], Keary and Brooks [38], Parasnis [24], Singh and Stephen [47] and similar studies. These sounding curve types characterize the electric typology of the geologic sequences of the study areas and highlights by 
pseudosections and geoelectric sections (Figures 17(a), 17(b), $18(\mathrm{a})$, and 18(b)). The acknowledgement of the type of sounding curves for the Batouri's and Ngoura's crystalline basements help to define Schlumberger vertical electrical sounding curves $(\mathrm{G}, \mathrm{H}, \mathrm{A}, \mathrm{QH}, \mathrm{KH}, \mathrm{HK}, \mathrm{HA}, \mathrm{HKH}$, and $\mathrm{KHK}$ ) which correspond to their subsurface structures. More than $80 \%$ of the Schlumberger electrical sounding curves are dominated by the $\mathrm{H}, \mathrm{QH}, \mathrm{KH}, \mathrm{HK}, \mathrm{HA}$, $\mathrm{HKH}$, and $\mathrm{KHK}$ types in the Colomine, Tassongo, and Mama II localities and the histogram of Colomine area (Figure 16) confirms this recovery of the sounding curve types referred above. These sounding curves are characterized by conductive and fractured/weathered levels inside granitic structures and can be interpreted as the electrical discontinuities or abnormal distributions of the subsurface resulting from weathering, fracturing, jointing, and faulting activities (Palacky et al., 1981; [21, 24, 30, 38]). The electrical discontinuities suggest an important heterogeneity of subsurface structures and put in case favored areas of mineral and groundwater targets in the crystalline basements (Palacky et al., 1981; [21, 24, 30, 38]).

The electrical characteristics (resistivity $\rho$ and thickness $e_{p}$ ) of each geological layer, resulting from the $1 \mathrm{D}$ inversions of the apparent resistivity as a function of depth through Schlumberger electrical soundings using the method described by Koefoed [32], suggest that the 1D geoelectrical models from various sounding curve types correspond to crystalline basements. Meanwhile, Chapellier [25], Oladapo et al. [44], and Kumar et al. [1] correlate the 1D geoelectrical models with the $1 \mathrm{D}$ geological models proposed for the same subsurface sections. In addition, the geological reconnaissance (observations on outcrops and goldmine pits) and data from previous studies (e.g., [27, 29, 42-45, 48]) help to design lithological 1D models related to each type of sounding curves through $1 \mathrm{D}$ geoelectrical models obtained. Correlation between geoelectrical and geological models in the same region help to define and propose geoelectrical and lithological 1D models for the crystalline basements through the geometrical and electrical characteristics of geological layer models: topsoil ( $0.5 \mathrm{~m}<e_{p}<3 \mathrm{~m} ; 600<\rho<3000 \Omega$.m), lateritic soils $\left(3<e_{p}<20 \mathrm{~m} ; \quad 1000<\rho<4000 \Omega . \mathrm{m}\right), \quad$ conductive layer $\left(5<e_{p}<110 \mathrm{~m} ; 100<\rho<1000 \Omega . \mathrm{m}\right)$, fractured/weathered granite $\left(20<e_{p}<60 \mathrm{~m} ; 1000 / 5000<\rho<3000 / 9000 \Omega\right.$.m $)$, clayey layer $\left(5<e_{p}<20 \mathrm{~m} ; 600 / 1500<\rho<2000 / 3500\right.$ (dry) $\Omega . \mathrm{m})$, and fresh granites $(\rho>4000 \Omega . \mathrm{m})$. It is therefore acknowledged that the Batouri-Ngoura's crystalline basements exhibit various lithological models which are particularly characterized by conductive layers and fractured/weathered granites. The conductive layers and fractured/weathered granites (Figures 20-27) confirm the discontinuity of subsurface structure proof by the Schlumberger electrical sounding curves. They depict proper hydrogeological and ore bodies occurring conditions for an efficient evaluation of the groundwater resources and mineral potential within the Batouri-Ngoura's basements $[1,22,24,30,38,49]$. The lithological dominant 1D models from the H-, QH-, KH-, HK-, HA-, HKH-, and KHK-type curves for Colomine, Tassongo, and Mama II (Figures 20 and 22-27), show that the crystalline basements in those localities have favorable conditions for mineral and groundwater prospecting. Thus, the $1 \mathrm{D}$ inversion of Schlumberger vertical electrical soundings using the method described by Koefoed [32] is the efficient background in the characterization of the typology of sounding curves and the location of favored areas of mineral and groundwater targets in the crystalline basements.

\section{Conclusion}

The vertical electrical sounding data acquisition in the Batouri and Ngoura subdivisions (East-Cameroon) along forty-one (41) profiles using the resistivity method has permitted to carry out an investigation of the subsurface layering, mineral potential, and groundwater resource characteristics until $120 \mathrm{~m}$ depth. Results of this investigation were presented as typology of sounding curves, mapping of the curve types, pseudosection,s and geoelectric and lithological sections. Pseudosection and geoelectric section characteristics reveal two to five layers underground and present the vertical changes of layers. The mapping of the curve types presents the horizontal variety of layers. The sounding curves show the variation of the resistivity with depth depending on the electric properties and tectonic activities of the geologic sequences in the subsurface. From the qualitative interpretation of VES curves, the subsurface layering is depicted by nine (09) types of sounding curves (G, H, A, QH, KH, HK, HA, HKH, and $\mathrm{KHK}$ ) characterizing the vertical changes and the typology of sounding curves in the East Cameroon crystalline basements. The lithology of subsurface in the study area is dominated (more than $80 \%$ ) by geoelectrical and lithological 1D models derived by the H-, QH-, KH-, HK-, HA-, $\mathrm{HKH}-$, and KHK-type curves characterized by an abnormal distribution of resistivity in depth. The abnormal distribution put in case conductive layers and fractured/weathered granites, which depict proper hydrogeological and mining conditions. Thus, the resistivity method applied in this study bring information of target zones for the mining and groundwater investigations in the regions crossed by crystalline basements.

\section{Data Availability}

The data in this article is an exclusive property of Artisanal and Small Scale Unit at the Ministry of Mines, Industry \& Technological Development and cannot be totally public. Some of this data was put to the public service so that reviewers could verify the reliability of the results. So, if reviewers need the raw data in this study, he send me your request.

\section{Conflicts of Interest}

The authors declare that they have no conflicts of interest. 


\section{Acknowledgments}

The authors are grateful to the Artisanal and Small Scale Unit at the Ministry of Mines, Industry \& Technological Development for providing the Syscal current IRIS instrument for field survey and data collection.

\section{References}

[1] R. Kumar, A. K. Tiwari, G. S. Yadav, and N. P. Singh, "Geohydrological investigation using vertical electrical sounding at Banaras Hindu University," International Journal of Research in Engineering and Technology, vol. 3, pp. 252-256, 2014.

[2] M. L. Boaka à Koul, R. Yongue-Fouateu, and P.-D. Ndjigui, "The alluvial sapphire profiles of Mayo Kewol placer in the Adamawa region (North-Cameroon): Granulometric and mineralogical features," Journal of African Earth Sciences, vol. 56, no. 2-3, pp. 121-126, 2010.

[3] V. Hodireva and D. Korpechkov, "Heavy mineral assemblages in Devonian sandstones and quaternary sediments in Latvia," 25th International Applied Geochemistry Symposium 2011, 2011, pp. 49-55, Rovaniemi, Finland, August 2011.

[4] S. N. Kanouo, K. Zaw, F. R. Yongue et al., "U-Pb zircon age constraining the source and provenance of gem-bearing late Cenozoic detrital Deposits, Mamfe Basin, SW Cameroon," Resource Geology, vol. 62, no. 3, pp. 316-324, 2012.

[5] S. N. Kanouo, "Geology of the western Mamfe corundum deposits, SW region Cameroon: petrography, geochemistry, geochronology, genesis, and origin," Unpublished $\mathrm{PhD}$ Thesis, University of Yaounde I, 2014.

[6] B. M. McClenaghan, "Overview of processing methods for recovery of indicator minerals from sediment and bedrock samples," Workshop in the 25th International Applied Geochemistry Symposium 2011, 2011, p. 72, 2011.

[7] J. B. Chaussier and J. Morer, Manuel du Prospecteur Minier. Manuel et Méthodes $N^{\circ} 2$ B.R.G.M, 1981.

[8] H. E. Macdonald, Handbook of Gold Exploration and Evaluation, Woodhead Publishing Limited and CRC Press LLC, 2007.

[9] M. Cornachia and R. Dars, "Un trait majeur du continent Africain," Les linéaments centrafricains du Cameroun au golfe d'Aden, Bulletin de la Société Géologique de France, vol. 25, pp. 101-109, 1983.

[10] P. Rolin, "La zone de décrochement panafricain des Oubanguides en République Centrafricaine," Comptes Rendus de l'Académie des Sciences de Paris, vol. 320, pp. 63-69, 1995.

[11] H. Mvondo, S. W. J. den Brok, and J. Mvondo Ondoa, "Evidence for symmetric extension and exhumation of the Yaounde nappe (Pan- African fold belt, Cameroon)," Journal of African Earth Sciences, vol. 36, no. 3, pp. 215-231, 2003.

[12] H. Mvondo, S. Owona, J. Mvondo Ondoa, and J. Essono, "Tectonic evolution of the Yaoundé segment of the Neoproterozoic Central African Orogenic Belt in southern Cameroon," Canadian Journal of Earth Sciences, vol. 44, no. 4, pp. 433-444, 2007.

[13] J. Gazel and C. Giraudie, "Notice Explicative Sur la Région Abong-Mbang Ouest et Batouri de la Carte Géologique de Reconnaissance," Mémoire du BRGM, No 92. Direction des Mines et de la Géologie, Cameroun, 1965.

[14] J. M. Regnoult, Synthèse géologique du Cameroun, DMG/MINMEE, 1986.
[15] D. H. Gouet, S. P. Assembe, A. Meying, M. Bikoro Bialou, J. K. Haskandi, and T. Ndougsa-Mbarga, "Combined geoelectrical approach DC and IP methods in the identification of the mineralized bodies parallel to the NE-SW tectonic line of Kadei River: case of quartz or pegmatite gold bearing veins of Ngoura Subdivision (East Cameroon)," International Journal of Geosciences, vol. 7, no. 7, pp. 891-903, 2016.

[16] J. B. Olinga, J. E. Mpesse, D. Minyem, V. Ngako, T. Ndougsa Mbarga, and G. E. Ekodeck, "The Awaé - Ayos strike-slip shear zones (Southern-Cameroon): geometry, kinematics and significance in the late Panafrican tectonics," Neues Jahrbuch für Geologie und Paläontologie - Abhandlungen, vol. 257, no. 1, pp. 1-11, 2010.

[17] E. Njonfang, V. Ngako, C. Moreau, P. Affaton, and H. Diot, "Restraining bends in high temperature shear zones: The "Central Cameroon Shear Zone", Central Africa," Journal of African Earth Sciences, vol. 52, no. 1-2, pp. 9-20, 2008.

[18] S. Mbom-Abane, Investigation géophysique en bordure du Craton du Congo (région d'Abong-Mbang/Akonolinga, Cameroun) et implications structurales, Thèse Doctorat d'Etat ès Sciences, Université de Yaoundé I, 1997.

[19] A. Meying, T. Ndougsa Mbarga, and E. Manguelle-Dicoum, "Evidence of fractures from the image of the subsurface in the Akojolinga-Ayos area (Cameroon) by combining the classical and the Bostick approaches in the interpretation of audiomagnetotelluric data," Journal of Geology and Mining Research, vol. 1, pp. 159-171, 2009.

[20] T. Ndougsa-Mbarga, A. Meying, D. Bisso, D. Y. Layu, K. K. Sharma, and E. Manguelle-Dicoum, "Audiomagnetotellurics (AMT) soundings based on the Bostick approach and evidence of tectonic features along the northern edge of the Congo Craton, in the Messamena/Abong-Mbang area (Cameroon)," Journal of Indian Geophysical Union, vol. 15, pp. 145-159, 2011.

[21] M. J. Jones, "The weathered zone aquifers of the basement complex areas of Africa," Quarterly Journal of Engineering Geology and Hydrogeology, vol. 18, no. 1, pp. 35-46, 1985.

[22] D. H. Gouet, T. Ndougsa-Mbarga, A. Meying, S. P. Assembe, and A. D. Man-Mvele Pepogo, "Gold mineralization channels identification in the Tindikala-Boutou area (Eastern-Cameroon) using geoelectrical (DC \&amp; IP) methods: a case study," International Journal of Geosciences, vol. 4, no. 3, pp. 643-655, 2013.

[23] D. H. Gouet, A. Meying, S. P. Assembe, and T. NdougsaMbarga, "Clay minerals channels identification in the Tindikala-Boutou area (eastern-Cameroon) along the Kadey River using direct current (DC) method," Journal of Geoscience and Environment Protection, vol. 3, no. 6, pp. 123-133, 2015.

[24] D. S. Parasnis, Principles of Applied Geophysics, Chapman and Hall, London, England, 5th edition, 1997.

[25] D. Chapellier, Prospection Électrique en Surface. Cours de géophysique, Université de Lausanne, Institut Français de Pétrole, 2000.

[26] J. Kiberu, "Induced polarization and resistivity measurements on a suite of near surface soil samples and their empirical relationships to selected measured engineering parameters," MSc thesis submitted at International Institute for GeoInformation Science and Earth Observation (ITC), Enschede, 2002.

[27] J. O. Coker, "Vertical electrical sounding (VES) methods to delineate potential groundwater aquifers in Akobo area, 
Ibadan, south-western, Nigeria," Journal of Geology and Mining Research, vol. 4, pp. 5-42, 2012.

[28] J. C. Egbai, "Vertical electrical sounding for the investigation of clay deposit in Orerokpe, Delta state," Journal of Emerging Trends in Engineering and Applied Sciences, vol. 2, pp. 260265, 2011.

[29] J. Raimi, M. S. Abdulkarim, I. Hamidu, and A. S. Arabi, "Application of Schlumberger vertical electrical sounding for determination of suitable sites for construction of boreholes for irrigation scheme within a basement complex," International Journal of Multidisciplinary Sciences and Engineering, vol. 2, no. 6, pp. 81-84, 2011.

[30] W. M. Telford, L. P. Geldart, R. E. Sheriff, and D. A. Keys, Applied Geophysics, Cambridge University press, 2nd edition, 1990.

[31] J. Jenny, M. Borreguero, and A. Burgisser, Instruction Manual, Winsev-6, Electrical sounding processing for Windows, 2004.

[32] O. Koefoed, "Resistivity Sounding Measurements, Ser," in Methods in Geochemistry and Geophysics 14A, Geosounding Principles 1, p. 276, Elsevier, Amsterdam Oxford-New York, 1979.

[33] U. C. Das and S. K. Verma, "Digital linear filter for computing type curves for the two-electrode system of resistivity sounding," Geophysical Prospecting, vol. 28, no. 4, pp. 610-619, 1980.

[34] O. Koefoed, "A fast method for determining the layer distribution from the raised kernel function in geoelegtrical sounding," Geophysical Prospecting, vol. 18, no. 4, pp. 564-570, 1970.

[35] O. Koefoed, "Progress in the direct interpretation of resistivity soundings: an algorithm," Geophysical Prospecting, vol. 24, no. 2, pp. 233-240, 1976.

[36] M. H. Loke, Electrical Imaging Surveys for Environmental and Engineering Studies. A Practical Guide to 2-D and 3-D Surveys, p. $61,2000$.

[37] B.-Y. Su and J.-H. Yue, "Research of the electrical anisotropic characteristics of water-conducting fractured zones in coal seams," Applied Geophysics, vol. 14, no. 2, pp. 216-224, 2017.

[38] P. Keary and M. Brooks, An Introduction to Geophysical Exploration, Blackwell Scientific Publications, 2nd edition, 1991.

[39] G. Keller and F. Frischknecht, Electrical Methods in Geophysical Prospectina, Peramon Press Naamloze Vennootschap, 1970.

[40] Y. Koussoubé, A. N. Savadogo, and E. S. Nakolendoussé, "Les différentes Signatures des fractures de Socle Cristallin en zone Sahélo-Soudanienne du Burkina Faso (Bassin Versant de Bidi, Province du Yatenga)," Télédétection, vol. 3, pp. 19-427, 2003.

[41] A. P. Sombo, F. W. Kouassi, B. C. Sombo, L. N. Kouamé, and E. G. Kouassi, "Contribution de la prospection électrique à l'identification et à la caractérisation des aquifères de socle du département de Sikensi (Sud de la Côte d'Ivoire)," European Journal of Scientific Research, vol. 64, pp. 206-219, 2011.

[42] G. J. Palacky, "Resistivity characteristics of geologic targets," in Electromagnetic Methods in Applied Geophysics, vol. 1 (theory) IG, No 3, M. N. Nabighian, Ed., pp. 53-129, Society of Exploration Geophysics, 1989.

[43] I. Akpabio and E. Ekpo, "Geoelectric investigation for groundwater development of southern part of Nigeria," The Pacific Journal of Science and Technology, vol. 9, pp. 219-226, 2008.

[44] M. I. Oladapo, O. O. Adeoye-Oladapo, and T. O. Alao, "Geoelectric study of coal deposits at Unwana/Afpiko area of Southeastern Nigeria," Journal of Applied Sciences Research, vol. 4, pp. 1534-1545, 2008.
[45] O. M. Alile, O. Ujuanbi, and I. A. Evbuomwan, "Geoelectric investigation of groundwater in Obaretin - Iyanomon locality, Edo state, Nigeria," Journal of Geology and Mining Research, vol. 3, pp. 13-20, 2011.

[46] J. H. Shoqeir, H. Hoetzl, and A. Flexer, "Integration of electrical resistivity and electromagnetic radiation methods for fracture flow system detection," International Journal of Geosciences, vol. 5, no. 8, pp. 863-875, 2014.

[47] S. B. Singh and J. Stephen, "Deep resistivity sounding studies in detecting shear zones: a case study from the southern granulite terrain of India," Journal of Asian Earth Sciences, vol. 28, no. 1, pp. 55-62, 2004.

[48] D. Boiero, A. Godio, M. Naldi, and E. Yigit, "Geophysical investigation of a mineral groundwater resource in Turkey," Hydrogeology Journal, vol. 18, no. 5, pp. 1219-1233, 2010.

[49] R. H. Burger, F. A. Sheehan, and C. H. Jones, Introduction to Applied Geophysics: Exploring the Shallow Subsurface, w. w. Norton \& Company, Inc., 500 Fifth. Avenue, New York, 2006. 